\title{
Antitumoral and antimetastatic activity of Maitake D-Fearch Paper triple-negative breast cancer cells
}

\author{
Eliana Noelia Alonso ${ }^{1, *}$, María Julia Ferronato ${ }^{1, *}$, María Eugenia Fermento ${ }^{1}$, \\ Norberto Ariel Gandini ${ }^{1}$, Alejandro López Romero ${ }^{2}$, Josefina Alejandra Guevara ${ }^{1}$, \\ María Marta Facchinetti ${ }^{1}$ and Alejandro Carlos Curino ${ }^{1}$ \\ ${ }^{1}$ Laboratorio de Biología del Cáncer, Instituto de Investigaciones Bioquímicas de Bahía Blanca (INIBIBB), Universidad \\ Nacional del Sur (UNS)-CONICET, Departamento de Biología, Bioquímica y Farmacia (UNS), Bahía Blanca, Argentina \\ ${ }^{2}$ Departamento de Hematología, IACA Laboratorios, Bahía Blanca, Argentina \\ *These authors contributed equally to this work
}

Correspondence to: Alejandro Carlos Curino, email: acurino@criba.edu.ar

Keywords: Maitake D-Fraction; mushroom; triple-negative breast cancer; antitumoral; antimetastatic

Received: May 09, $2017 \quad$ Accepted: April 05, $2018 \quad$ Published: May 04, 2018

Copyright: Alonso et al. This is an open-access article distributed under the terms of the Creative Commons Attribution License 3.0 (CC BY 3.0), which permits unrestricted use, distribution, and reproduction in any medium, provided the original author and source are credited.

\section{ABSTRACT}

Triple-negative breast cancer (TNBC) is associated with poor prognosis, high local recurrence rate and high rate of metastasis compared with other breast cancer subtypes. In addition, TNBC lacks a targeted therapy. This scenario highlights the need for novel compounds with high potential for TNBC treatment. In this regard, natural products are important sources of anticancer drugs. D-Fraction, a proteoglucan extracted from the edible and medicinal mushroom Grifola frondosa (Maitake), is a dietary supplement that has been shown to exert both immunostimulatory and immune-independent antitumoral effects on some cancer types. However, its antitumoral potential in TNBC is unknown. Therefore, we employed TNBC cells to investigate if $D$-Fraction is able to attenuate their aggressive phenotype. We found that D-Fraction decreases MDA-MB-231 cell viability through apoptosis induction and reduces their metastatic potential. D-Fraction increases cell-cell adhesion by increasing $\mathrm{E}$-cadherin protein levels and $\beta$-catenin membrane localization, and increases cell-substrate adhesion. D-Fraction also decreases cell motility by affecting actin cytoskeleton rearrangements, and proteolytic activity of MMP-2 and MMP-9. Furthermore, D-Fraction decreases the invasive capacity of MDA-MB-231 cells. In concordance, D-Fraction retards tumor growth and reduces lung metastases in a xenograft model. Altogether, these results suggest the potential therapeutic role of D-Fraction in aggressive TNBC.

\section{INTRODUCTION}

Despite advances in the diagnosis and treatment of human malignancy, cancer remains among the leading causes of morbidity and mortality worldwide [1], with 8.2 million deaths attributed to cancer in 2012 [2]. Breast cancer is, by far, the most frequently diagnosed malignant neoplasm and a leading cause of cancer death in females worldwide [3], accounting for $25.1 \%$ of cancer diagnoses (1.67 million women) and $14.7 \%$ of cancer deaths (521,907 women) in 2012 [2]. Approximately $10-20 \%$ of all mammary tumors are TNBC.
TNBC is defined immunohistochemically as a mammary carcinoma that lacks expression of estrogen receptor (ER), progesterone receptor (PR) and human epidermal growth factor receptor 2 (HER2) [4]. This tumor phenotype is associated with high proliferative rate, early and high local recurrence rate $[5,6]$, high rate of metastasis compared with other breast cancer subtypes [6] and poor survival rates $[5,6]$. In addition to these aggressive characteristics, TNBC lack a targeted therapy [7]. Their lack of expression of ER, PR and HER2 makes them insensitive to endocrine and HER2-based therapies. Hence, TNBC is currently treated with standard cytotoxic 
chemotherapy [8]. In this context, there is a clear need for novel compounds with low toxicity and high potential for treatment or chemoprevention of TNBC.

Mushrooms have attracted the interest of many food and biopharmaceutical areas given their well known nutritional and medicinal values. In cancer research, natural products have played a very important role in the drug discovery and development process [9] and particularly, many mushroom species are considered small pharmaceutical factories producing hundreds of compounds with biological activity [10]. Grifola frondosa, commonly known as Maitake, is an edible and medicinal mushroom that has been used for centuries by the oriental medicine, especially in countries like China, India, Japan and Korea [11]. D-Fraction is a standardized form of protein-bound $\beta$-glucans (proteoglucan) extracted from the fruit bodies of Maitake, considered as a dietary supplement. While most mushroom-derived $\beta$-glucans have a 1,3 main chain with 1,6 branches only, $\beta$-glucans found in D-Fraction have a unique and complex structure, containing both a 1,6 main chain having a greater degree of 1,3 branches, and a 1,3 main chain having 1,6 branches $[12,13]$. Animal studies and early clinical trials showed that ingestion of Maitake D-Fraction is safe with no toxic or adverse effects and that may even provide health benefits and improvements in the treatment of some types of cancer $[12,14]$.

The antitumoral activity of D-Fraction has been the focus of multiple investigations. Initially this effect was attributed exclusively to their immunomodulatory capacity. Using different animal models, it was found that D-Fraction not only activates effectors cells of both the innate [14-20] and adaptive [18, 21] immune system but also potentiates the production and release of lymphokines and interleukins that amplify immune responses. More recently, increasing evidence shows that D-Fraction also exhibits immune-independent antitumoral effects on some types of cancer. Thus, the proteoglucan has antiproliferative or cytotoxic effect on PC3 (prostate cancer) [22], T24 (bladder cancer), HepG2 (liver cancer), U89 (brain cancer), HL60 (leukemia) [23], MCF7 and LM3 (breast cancer) [23-25], ACHN cells (kidney cancer) $[26,27]$ and three canine cancer cell lines, but it does not affect the viability of A549 (lung cancer) and AGS cells (gastric cancer) [28].

Particularly with regard to breast cancer, we have demonstrated that Maitake D-Fraction decreases the viability of hormone-dependent MCF7 cells [24] and modulates the expression of genes associated with cell proliferation, cell death, migration, invasion and metastasis among others [29]. Moreover, considering that breast cancer is a heterogeneous disease constituted by a broad spectrum of tumor subtypes, we demonstrated that D-Fraction decreases the viability and metastatic potential of hormone-independent LM3 cells in culture and reduces the tumor burden and the number of lung metastases in the
LM3 syngeneic murine model [25]. However, it remains unknown whether Maitake D-Fraction has antitumoral effects in TNBC, an aggressive tumor subtype that have a limited number of treatment choices.

MDA-MB-231 is a human, highly metastatic, TNBC cell line that has been widely used as cell model to study TNBC development and progression and to investigate new drugs against TNBC. Therefore, in the present study we employed MDA-MB-231 cells to investigate the effect of Maitake D-Fraction on the cellular processes that are frequently deregulated in tumor cells and linked to development and malignancy of cancer. In addition, another TNBC cell line, the murine 4T1, was used to evaluate whether the effects of D-Fraction are cell lineindependent. These results will give information regarding the potential therapeutic use of D-Fraction in TNBC.

\section{RESULTS}

\section{Maitake D-Fraction decreases the viability of TNBC MDA-MB-231 and 4T1 cells through apoptosis induction}

To begin to investigate the antitumor effects of D-Fraction in TNBC, we first examined its effects on MDAMB-231 and 4T1 cell viability. For this purpose, the cells were treated with different concentrations of D-Fraction $(30,300,750,1500$ and $2250 \mu \mathrm{g} / \mathrm{mL})$ and for different incubation times $(24,48$ and $72 \mathrm{~h})$. Then, manual cell count and WST-1 assay were performed. As shown in Figure 1A, a decrease in the cell count of both TNBC cell lines was observed, being this effect dose- and time-dependent. The $\mathrm{IC}_{50}$ values of D-Fraction for MDA-MB-231 cells at 24, 48 and $72 \mathrm{~h}$ were $1050 \mu \mathrm{g} / \mathrm{mL}, 322.2 \mu \mathrm{g} / \mathrm{mL}$ and $238.2 \mu \mathrm{g} / \mathrm{mL}$, respectively. Similar $\mathrm{IC}_{50}$ values for $4 \mathrm{~T} 1$ cells were found, being $1077.7 \mu \mathrm{g} / \mathrm{mL}, 352 \mu \mathrm{g} / \mathrm{mL}$ and $314.5 \mu \mathrm{g} / \mathrm{mL}$ at 24,48 and $72 \mathrm{~h}$ respectively. Therefore, for the subsequent studies we chose the $\mathrm{IC}_{50}$ at $24 \mathrm{~h}$ of each cell line $(1050 \mu \mathrm{g} / \mathrm{mL}$ for MDA-MB-231 cells and $1077.7 \mu \mathrm{g} / \mathrm{mL}$ for $4 \mathrm{~T} 1 \mathrm{cells})$. The colorimetric WST-1 assay confirmed the decrease of cell viability induced by D-Fraction in the TNBC cell lines (data not shown).

In order to determine whether D-Fraction exerts a cytostatic or apoptotic effect in TNBC cells, we performed PI staining in MDA-MB-231 cells and quantified the percentage of cells in all cell cycle phases by flow cytometry. As shown in Figure 1B Maitake D-Fraction $\left(\mathrm{IC}_{50}, 24 \mathrm{~h}\right)$ increased the number of cells in the subG $\mathrm{G}_{0} / \mathrm{G}_{1}$ phase $(\mathrm{D}-$ Fraction $=8.92 \%$ vs vehicle $=0.96 \%, p<0.01)$ and decreased those in the $\mathrm{G}_{0} / \mathrm{G}_{1}$ phase, compared to vehicle $(\mathrm{D}-$ Fraction $=48.59 \%$ vs vehicle $=75.41 \%, p<0.001)$. These results suggest that Maitake D-Fraction decreases MDA-MB-231 cell viability through an induction in cell death. In order to corroborate if the increase in the number of cells in subG $\mathrm{G}_{0} / \mathrm{G}_{1}$ phase was due to an induction of apoptosis by Maitake, AV/PI staining was performed and 
examined by flow cytometry after $24 \mathrm{~h}$ of D-Fraction or vehicle treatment. As shown in Figure 1C the apoptotic cell population $(\mathrm{AV}+)$ increased from $12.11 \%$ in the vehicletreated cells to $34.31 \%$ in the D-Fraction treated cells ( $p$ $<0.001)$. Therefore, Maitake D-Fraction decreases MDAMB-231 cell viability through induction of apoptosis.

The PI3K/AKT and MAPK/ERK are pro-survival molecular pathways that are frequently hyper-activated in many solid tumors such as breast cancer. Therefore, we examined if D-Fraction affects the activation of these signal pathways. To this end, we first evaluated the levels of Aktand ERK1/2- phosphorylation in MDA-MB-231 cells after Maitake treatment. We found that D-Fraction attenuates Akt phosphorylation at Ser 473 (pAkt-S473) and ERK1/2 phosphorylation at Thr202/Tyr204 (PERK1/2), compared to vehicle treatment (Figure 1D). In agreement with the effect observed on pAkt-S473, we found that the levels of Bax expression remains constant but the expression of Bcl-2 decreases after D-Fraction treatment (Figure 1D). Similar results were obtained when 4T1 cells were used (data not shown). Altogether, these results suggest that D-Fraction may induce apoptosis through an attenuation of the pro-survival pathways PI3K-Akt and ERK, and through modulation of the $\mathrm{Bax} / \mathrm{Bcl}-2$ ratio.

\section{Maitake D-Fraction decreases the migratory capability of TNBC MDA-MB-231 and 4T1 cells}

In order to determine the antimetastatic potential of Maitake D-Fraction on TNBC cells its effect on cell migration was first evaluated through wound healing assays. Confluent monolayers of MDA-MB-231 and 4T1 cells were wounded and wound closure was observed by optical microscopy during $12 \mathrm{~h}$ of treatment. Under treatment with D-Fraction $\left(\mathrm{IC}_{50}\right)$, both TNBC cell lines decreased their migratory capability. Such effect was observed from $8 \mathrm{~h}$ of treatment onwards. At this time, uncovered wound area in D-Fraction-treated MDAMB-231 cells was $72.04 \%$ vs $35.47 \%$ in vehicle-treated cells ( $p<0.001$, Figure 2A). In 4T1 cells, the uncovered wound area under treatment with D-Fraction was $64.37 \%$ vs $50.76 \%$ under vehicle-treatment ( $p<0.001$, Figure $2 \mathrm{~B}$ ). Neither at $8 \mathrm{~h}$ nor at $12 \mathrm{~h}$ of treatment, the cellular viability of MDA-MB-231 and 4T1 was diminished (Supplementary Figure 1).

\section{Maitake D-Fraction affects the reorganization of the actin cytoskeleton of TNBC MDA-MB-231 cells}

Stress fibers are actin-rich structures that typically are associated with cell migration [30, 31]. Having seen the effect of Maitake D-Fraction on the migratory capability of MDA-MB-231 cells, we analyzed whether the proteoglucan alters the organization of the actin cytoskeleton of these cells by staining F-actin with rhodamine-conjugated phalloidin. As observed in Figure 2C, we found that the number of MDA-MB-231 cells with stress fibers was strongly reduced from $96.73 \% \pm 0.31$ to $4.95 \% \pm 1.12(p<0.001)$ after $12 \mathrm{~h}$ of Maitake D- Fraction treatment $\left(\mathrm{IC}_{50}\right)$. Furthermore, most of the D-Fraction-treated cells presented cortical actin staining. This result suggests that Maitake D-Fraction affects the organization of actin cytoskeleton reducing the presence of stress fibers, and is in concordance with the decreased migration of D-Fraction-treated MDA-MB-231 cells observed in the wound healing assay.

\section{Maitake D-Fraction decreases activity of MMP-2 and MMP-9 secreted by TNBC MDA-MB-231 cells}

There is a well-established relationship between high activity of matrix metalloproteinases (MMPs) and tumor progression of many cancer types [32-34]. In this context, we evaluated the effect of Maitake D-Fraction on the proteolytic activity of MMP-2 and MMP-9 secreted by TNBC MDA-MB-231 cells. By gelatin zymography, we detected that D-Fraction treatment $\left(\mathrm{IC}_{50}, 18 \mathrm{~h}\right)$ decreased MMP-2 activity by $51.06 \%$ with respect to vehicle treatment (red arrow, $p<0.001$ ) (Figure 3). Furthermore, as no effect was observed in MMP-9 activity at $18 \mathrm{~h}$ we performed longer treatments and observed that D-Fraction $\left(\mathrm{IC}_{50}, 24 \mathrm{~h}\right)$ decreases the activity of this secreted metalloprotease by $28.17 \%$ respect to control (red arrow, $p<0.05$ ) (Figure 3). These results suggest that Maitake D-Fraction reduces the capability of TNBC MDAMB-231 cells to degrade extracellular matrix (ECM), thereby hindering tumor invasion.

\section{Maitake D-Fraction promotes the intercellular adhesion and cell-substrate adhesion in TNBC MDA-MB-231 cells}

It is well known that alterations in the adhesion properties of tumor cells play a key role in the development and progression of cancer $[35,36]$. Particularly, the loss of cell-cell adhesion triggers epithelial-mesenchymal transition (EMT), a process known to contribute to the acquisition of migratory and invasive properties and favors the development of metastasis in cancer [37]. Hence, to investigate whether D-Fraction affects cell-cell adhesion we evaluated the effect of the proteoglucan on the expression of E-cadherin and $\beta$-catenin in MDA-MB-231 cells. These proteins are the major adhesion molecules at the level of the adherent junctions between epithelial cells [38, 39]. As shown in Figure 4A, we found that D-Fraction treatment $\left(\mathrm{IC}_{50}, 12 \mathrm{~h}\right)$ increases the expression of E-cadherin in MDA-MB-231 cells compared to vehicle treatment $(p<0.05)$ but does not affect the expression of $\beta$-catenin. However, despite not changing the total cellular abundance of $\beta$-catenin, we found that Maitake D-Fraction 
produced a change in its subcellular localization. It has been reported that cytoplasmic and/or nuclear localization of $\beta$-catenin correlates with poor prognosis in patients with breast cancer [40-45]. As shown in Figure 4B, we found that Maitake D-Fraction decreases the presence of $\beta$-catenin in the cytoplasm/nucleus of MDA-MB-231 cells $(p<0.001)$ and promotes its membrane localization $(p<0.01)$. These results suggest that $\mathrm{D}$-Fraction promotes the intercellular adhesion and the epithelial phenotype of tumor cells, thus decreasing their invasive potential.
On the other hand, we evaluated if Maitake D-Fraction affects the adhesion of MDA-MB-231 cells to the substrate. With this end, MDA-MB-231 cells were pre-treated with D-Fraction $\left(\mathrm{IC}_{50}, 12 \mathrm{~h}\right.$ ) or vehicle. Then, the cells were harvested and incubated for different times in 96-well plates. As shown in Figure 4C, after incubating cells for $10 \mathrm{~h}$ (vehicle 42.83 vs D-Fraction 57.60 adhered cells) and $12 \mathrm{~h}$ (vehicle 44.03 vs D-Fraction 57.43 adhered cells), D-Fraction significantly increased MDA-MB-231 cell adhesion compared to vehicle $(p<0.05)$. Therefore,

A
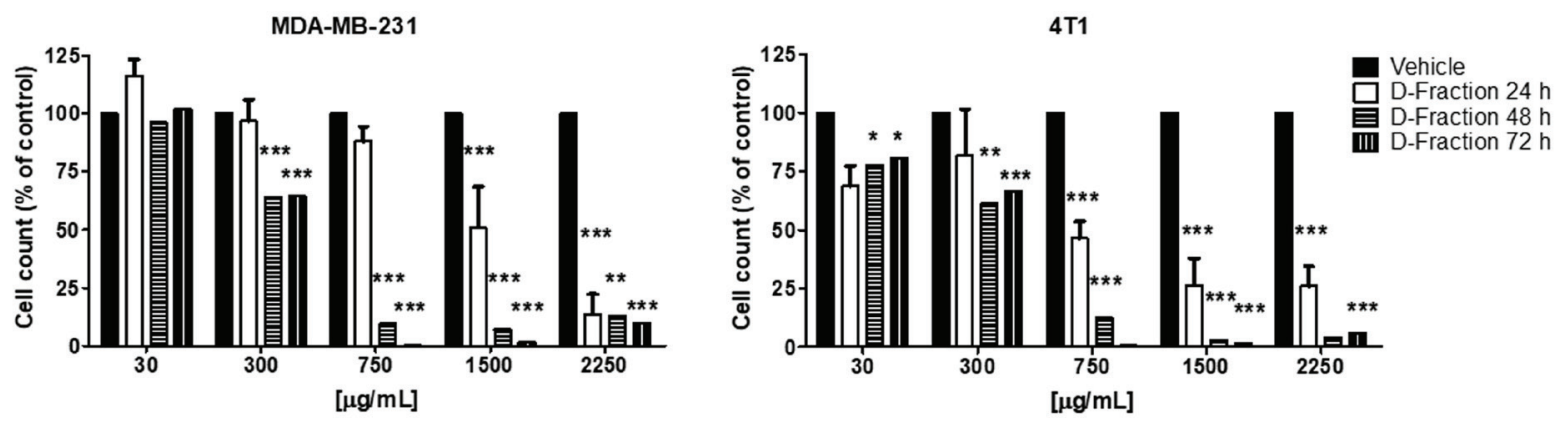

B
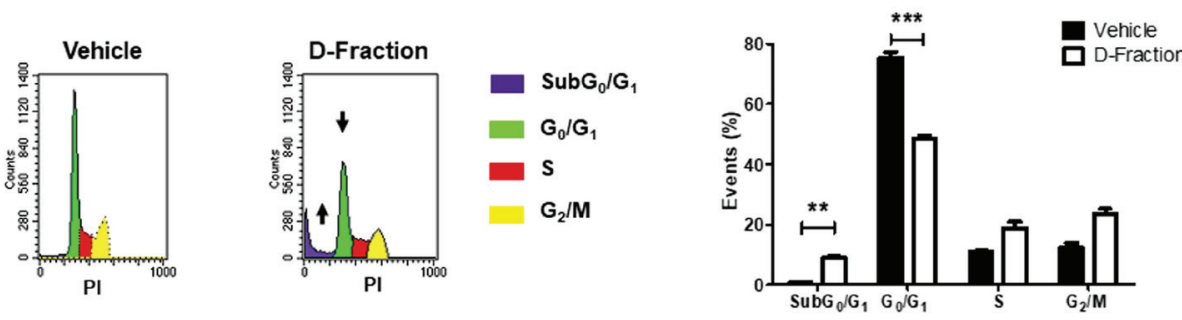

C
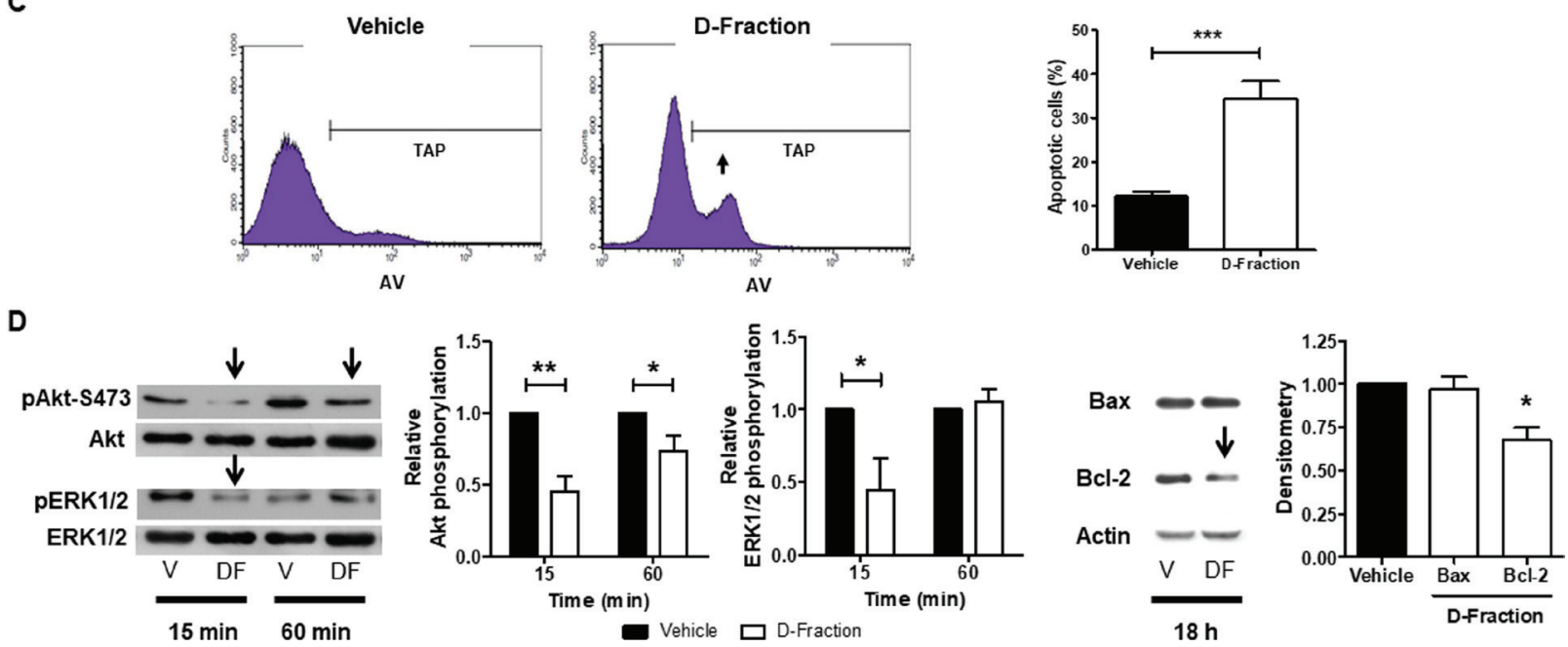

Figure 1: Maitake D-Fraction decreases the viability of TNBC MDA-MB-231 and 4T1 cells through apoptosis induction. (A) Cell count was assessed in MDA-MB-231 and 4T1 cells after 24, 48 or $72 \mathrm{~h}$ of treatment with different concentrations of D-Fraction or vehicle. Data show the percentage of cells in relation to vehicle-treated cells. The bars represent the mean $\pm \mathrm{SEM}$ of at least two independent experiments. (B) Cell cycle analysis of MDA-MB-231 cells after treatment with D-Fraction ( $\left.\mathrm{IC}_{50}, 24 \mathrm{~h}\right)$ or vehicle. The increase in $\operatorname{subG}_{0} / \mathrm{G}_{1}$ and the decrease in $\mathrm{G}_{0} / \mathrm{G}_{1}$ cell populations are indicated by arrows and plotted in a graph. Mean \pm SD of one representative experiment. Two-way ANOVA and Bonferroni post tests. (C) Apoptosis analysis of MDA-MB-231 cells after treatment with D-Fraction $\left(\mathrm{IC}_{50}, 24 \mathrm{~h}\right)$ or vehicle. The increase in the total apoptotic population (TAP) after D-Fraction treatment is indicated by an arrow and plotted in a graph. Mean \pm SD of one representative experiment. Student's $t$ test. (D) WB analysis for pAkt-S473, Akt, pERK1/2, ERK1/2, Bax and Bcl-2 proteins in MDA-MB-231 cells after treatment with D-Fraction ( $\mathrm{IC}_{50}, 15 \mathrm{~min}, 60 \mathrm{~min}$ and $\left.18 \mathrm{~h}\right)$ or vehicle. Representative blots of three independent experiments are shown. The densitometry mean \pm SD is depicted. Two-way ANOVA and Bonferroni post tests, and Student's $t$ test were performed. ${ }^{*} p<0.05,{ }^{* *} p<0.01,{ }^{* * *} p<0.001$. 
A

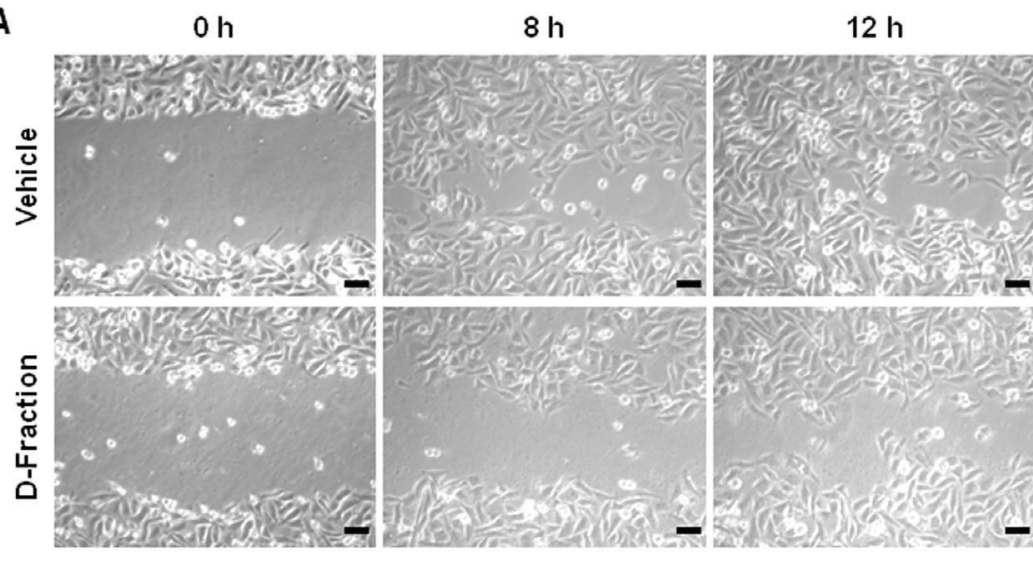

B

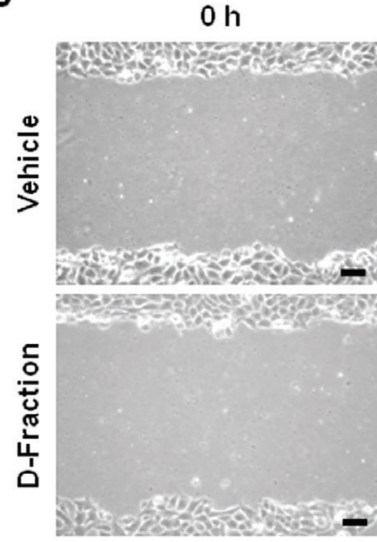

$8 \mathrm{~h}$

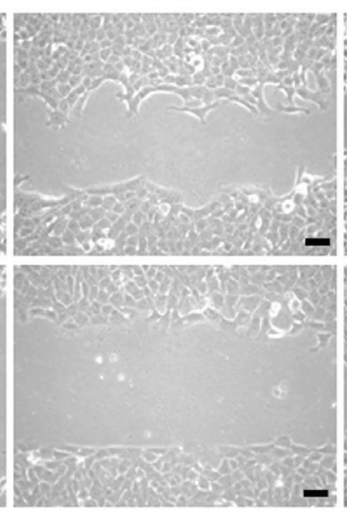

$12 \mathrm{~h}$

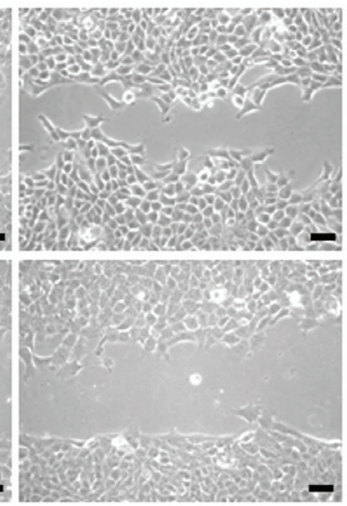

MDA-MB-231

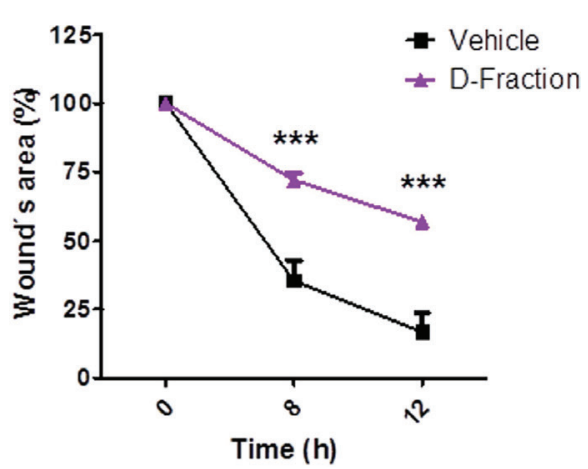

4T1

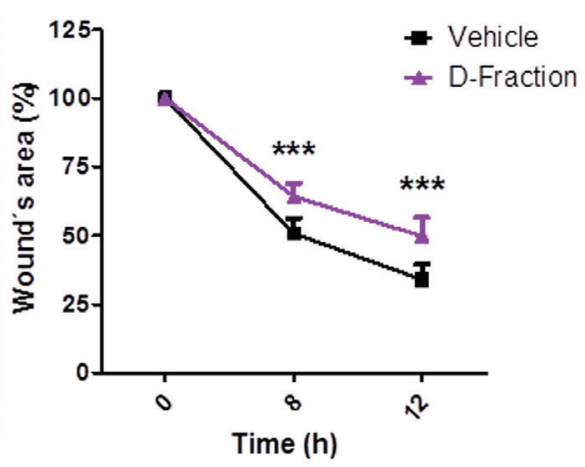

C
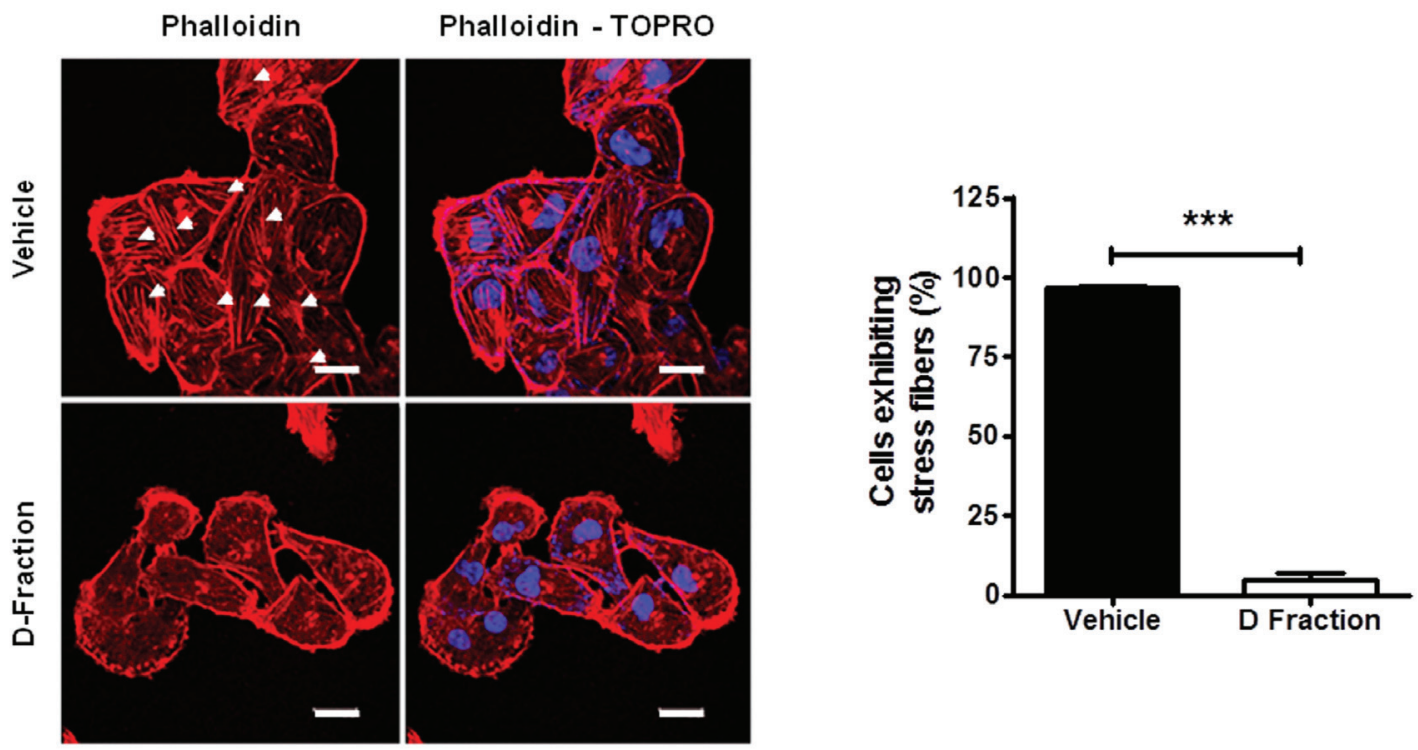

Figure 2: Maitake D-Fraction decreases migration of TNBC MDA-MB-231 and 4T1 cells and reduces the presence of stress fibers. Representative phase-contrast pictures of the wound healing assay of (A) MDA-MB-231 cells and (B) 4T1 cells under treatment with D-Fraction $\left(\mathrm{IC}_{50}\right)$ or vehicle. Magnification: 200×. The graphs represent the mean percentage $( \pm \mathrm{SD})$ of uncovered wound area taking the value at $0 \mathrm{~h}$ as $100 \%$ of one representative experiment. Two-way ANOVA and Bonferroni post tests were performed. (C) Representative fluorescence images of MDA-MB-231 cells stained with rhodamine-conjugated phalloidin (F-actin) and TOPRO (nuclei) after treatment with D-Fraction $\left(\mathrm{IC}_{50}, 12 \mathrm{~h}\right)$ or vehicle. Arrows indicate stress fibers. The graph represents the mean percentage $( \pm \mathrm{SD})$ of cells exhibiting stress fibers after treatment of one representative experiment. Magnification: $630 \times$, scale bars represent $20 \mu \mathrm{m}$. Student's $t$ test was applied. ${ }^{* * *} p<0.001$. 
Maitake D-Fraction is capable of increasing the adhesive response of TNBC MDA-MB-231 cells, suggesting that D-Fraction induces a less malignant phenotype.

\section{Maitake D-Fraction decreases the invasive capability of TNBC MDA-MB-231 and 4T1 cells}

The metastatic process begins with local tumor invasion into surrounding tissue, in which factors such as cell adhesion to the substrate, degradation of ECM and tumor cell motility play a key role [46-48]. Since the results of the previous sections show that Maitake D-Fraction affects these factors tending to decrease the metastatic potential of TNBC MDA-MB-231 cells, we decided to investigate the overall effect of D-Fraction on the invasive process. To do this, we evaluated the invasive capacity of tumor cells using transwell chambers (Millipore) with Matrigel. As shown in Figure 5A Maitake
D-Fraction treatment reduced the invasiveness of MDAMB-231 when compared with vehicle treatment (mean value of vehicle treatment $=71.96$ vs D-Fraction treatment $=27.54, p<0.001)$. In addition, we also found that D-Fraction decreases the invasive capability of 4T1 cells (mean value of vehicle treatment $=56.28$ vs D-fraction treatment $=43.38, p<0.01$; Figure $5 \mathrm{~B})$.

\section{Maitake D-Fraction retards tumor growth and reduces the number of lung metastases in a xenograft murine model of TNBC human cells}

Having demonstrated that Maitake D-Fraction decreases the viability and the metastatic potential of TNBC MDA-MB-231 and 4T1 cells grown in culture, we aimed to evaluate the antitumor and anti-metastatic activity of D-Fraction in vivo. Therefore, we employed an orthotopic model of human breast cancer MDA-MB-231
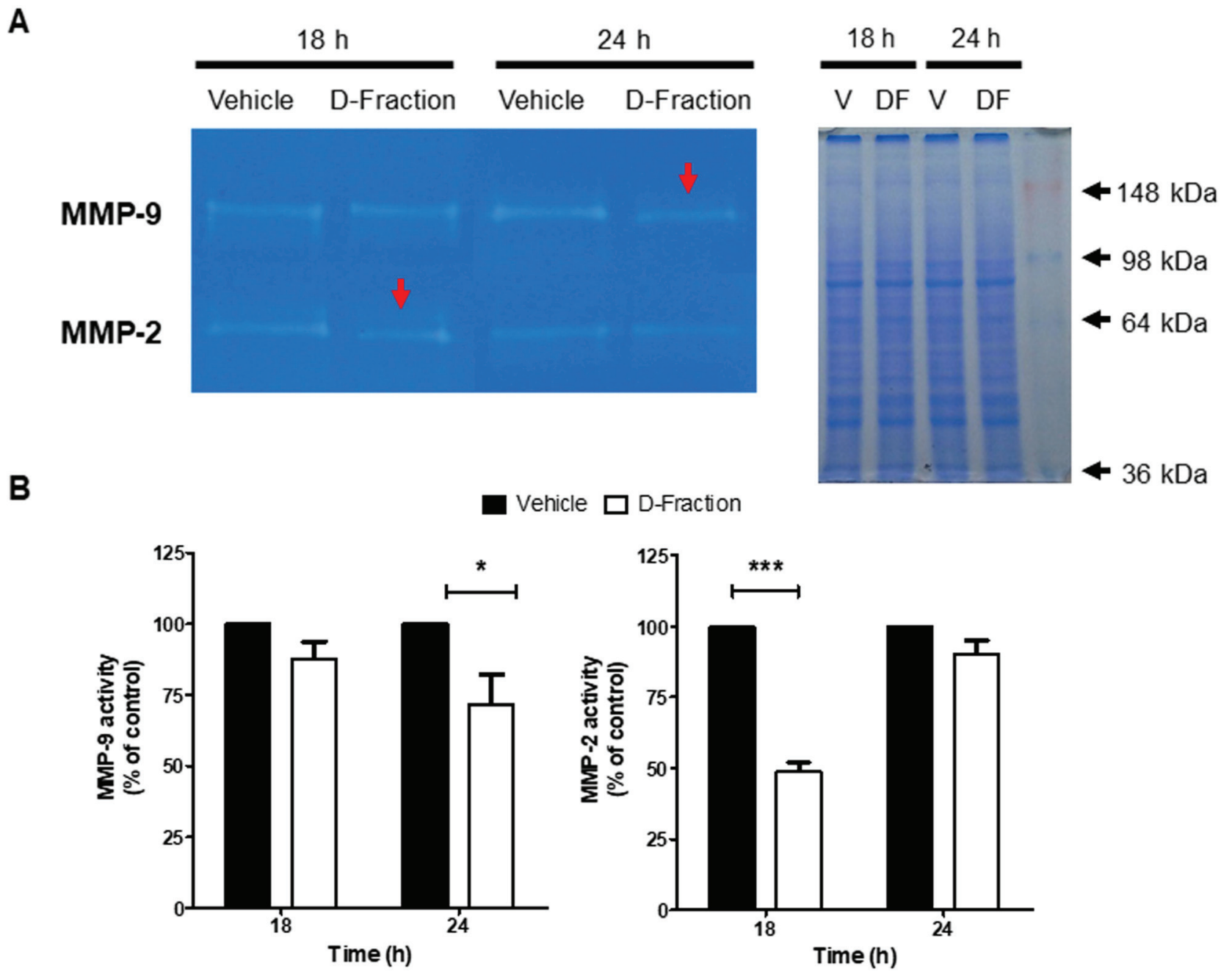

Figure 3: Maitake D-Fraction decreases the activity of MMP-2 and MMP-9 secreted by TNBC MDA-MB-231 cells. (A) Representative image of gelatinolytic bands obtained with the different CM and visualized using a transilluminator (left) and its parallel coomassie gel (right). (B) Activity of the MMPs after D-Fraction treatment, plotted as a percentage of the control. Gelatinolytic bands were measured with Fiji (Fiji Is Just ImageJ) and normalized to total protein concentration. Values are the mean \pm SEM of three independent experiments. Two-way ANOVA and Bonferroni post tests. ${ }^{*} p<0.05,{ }^{* * *} p<0.001$. 
A
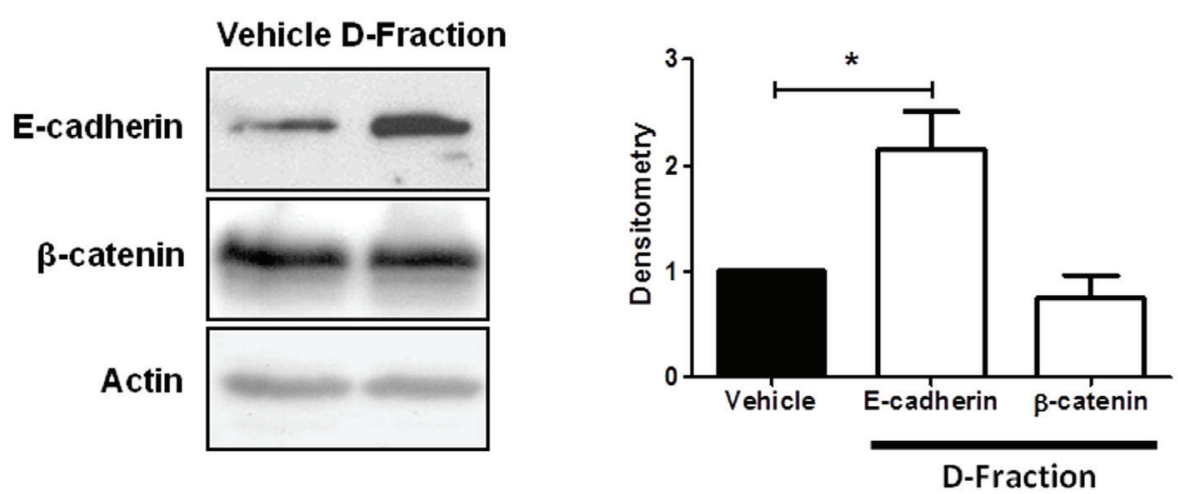

B
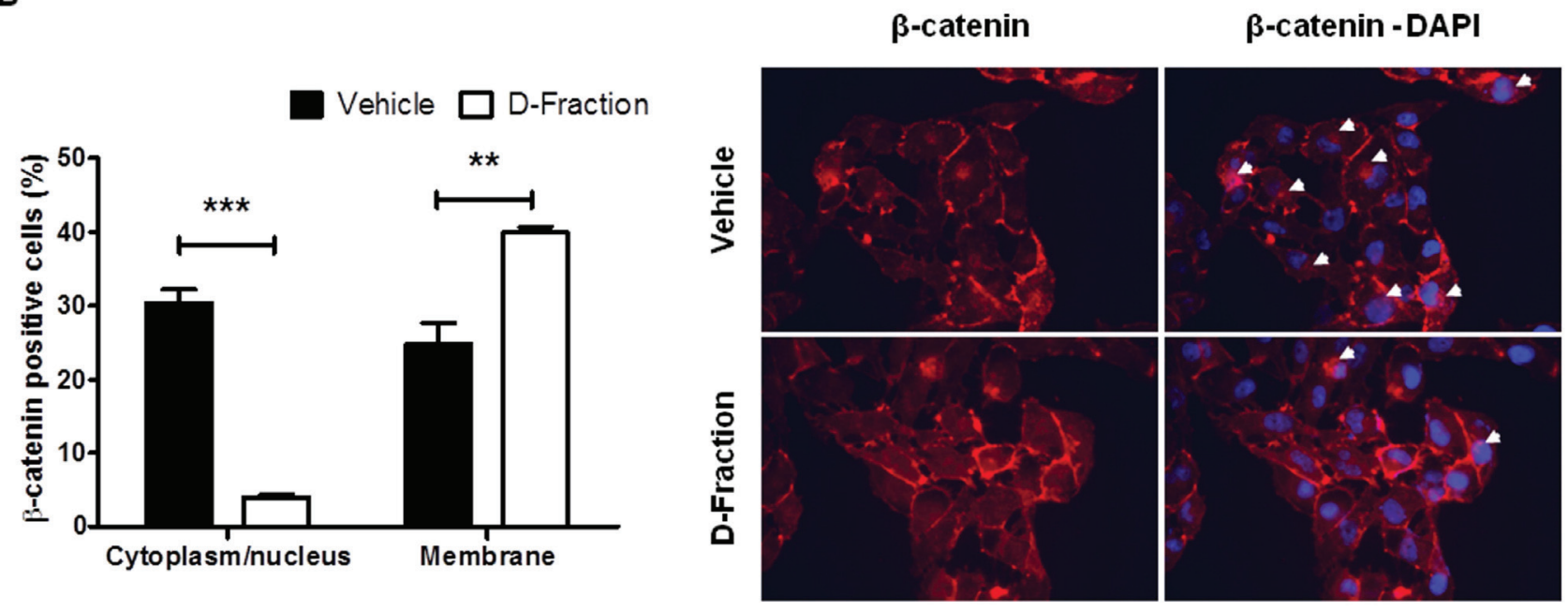

C

\section{Vehicle}
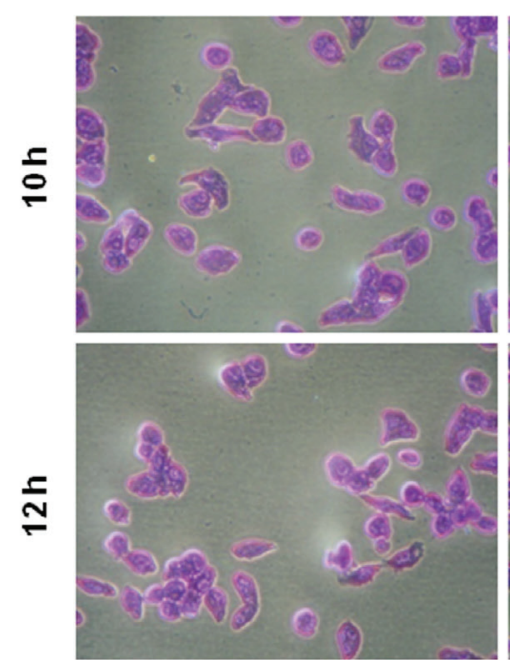

D-Fraction
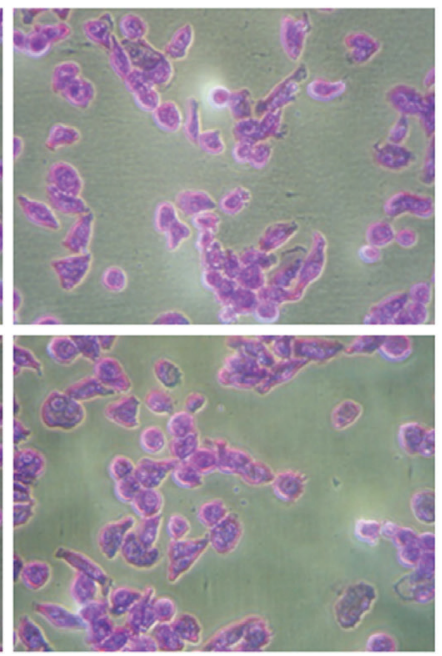

Figure 4: Maitake D-Fraction promotes the intercellular adhesion and cell-substrate adhesion in TNBC MDA-MB-231 cells. (A) WB analysis for E-cadherin and $\beta$-catenin protein in cells treatment with D-Fraction $\left(\mathrm{IC}_{50}, 12 \mathrm{~h}\right.$ ) or vehicle. Representative blots of at least two independent experiments and densitometry, mean \pm SD. Student's $t$ test. (B) IF for $\beta$-catenin after treatment with D-Fraction $\left(\mathrm{IC}_{50}, 12 \mathrm{~h}\right)$ or vehicle. The graph represents the proportion of cells (mean $\left.\pm \mathrm{SD}\right)$ with expression of $\beta$-catenin in cytoplasm/nucleus or membrane after treatment. Representative fluorescence images; arrows indicate the cytoplasm localization of $\beta$-catenin. Magnification: 400x. Student's $t$ test. (C) Cell adhesion assay after treatment with D-Fraction $\left(\mathrm{IC}_{50}, 12 \mathrm{~h}\right)$ or vehicle. The graph represents the number of adhered cells (mean \pm SD) after treatment of one representative experiment. Representative pictures of cell adhesion assay. Magnification: 400x. Two-way ANOVA and Bonferroni post tests. ${ }^{*} p<0.05,{ }^{* *} p<0.01,{ }^{* * *} p<0.001$. 
cells. This model allows to evaluate both the primary tumor growth and the development of lung metastases [49]. We found that Maitake D-Fraction retarded tumor growth when compared to the vehicle-treated mice (Figure 6A). Indeed, D-Fraction-treated mice presented smaller tumors than vehicle-treated mice $\left(544.1 \mathrm{~mm}^{3}\right.$ vs. $862.7 \mathrm{~mm}^{3}$; $p<0.01)$. In addition, the lungs fixed in Bouin's solution were examined. As shown in Figure 6B, small superficial metastases were detected and quantified. We found a lower number of lung metastases per animal in D-Fractiontreated mice $($ median $=1$, range $0-3$ ) than in the vehicle-treated mice $($ median $=4$, range $3-21)(p<0.05$; Figure 6C). Finally, the presence of metastases were confirmed by staining with Hematoxylin and Eosin (H\&E) (Figure 6D). Altogether, these in vivo results demonstrate the antitumoral and antimetastatic activity of D-Fraction in a xenograft murine model of TNBC, and are in agreement with the in culture effects of D-Fraction on TNBC cells.

\section{DISCUSSION}

Breast cancer, the most common cancer in women worldwide, is a heterogeneous disease, composed of a broad spectrum of tumor subtypes with different biological characteristics and clinical behavior [6]. The primary breast cancer markers traditionally used in routine clinical practice to establish the diagnosis, prognosis and therapy of disease are ER, PR and HER2 [50]. Thus, tumors that express ER and $P R$ are treated with agents that interfere with hormone production or action, plus chemotherapy. Tumors with overexpression and/or gene amplification of HER2 are treated with agents that inhibit HER2, plus chemotherapy [8]. On the contrary, there is no targeted therapy for tumors that do not express any of three markers (triple negative) [51] so they can only be treated with chemotherapy [8]. Therefore, new effective and safe drugs for the treatment of highly aggressive TNBC are urgently needed to be found.

In addition to the excellent nutritional value, medicinal aspects of mushrooms extracts or their metabolites make them excellent candidates for the search and development of new drugs [11, 23, 52]. In this field, many mushroom species are valued as small pharmaceutical factories producing hundreds of bioactive compounds, many of which have shown to exert therapeutic action against the development of cancer $[10,11]$. Such is the case of D-Fraction, a bioactive proteoglucan extracted from Grifola frondosa mushroom, which in turn is a dietary supplement..

A

MDA-MB-231
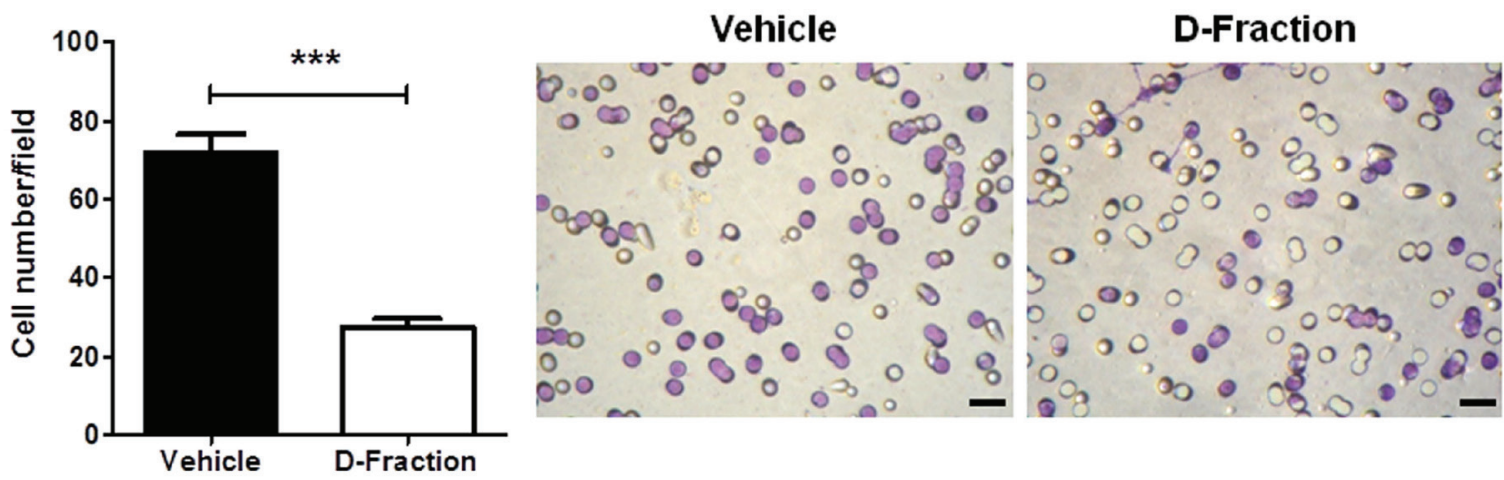

B
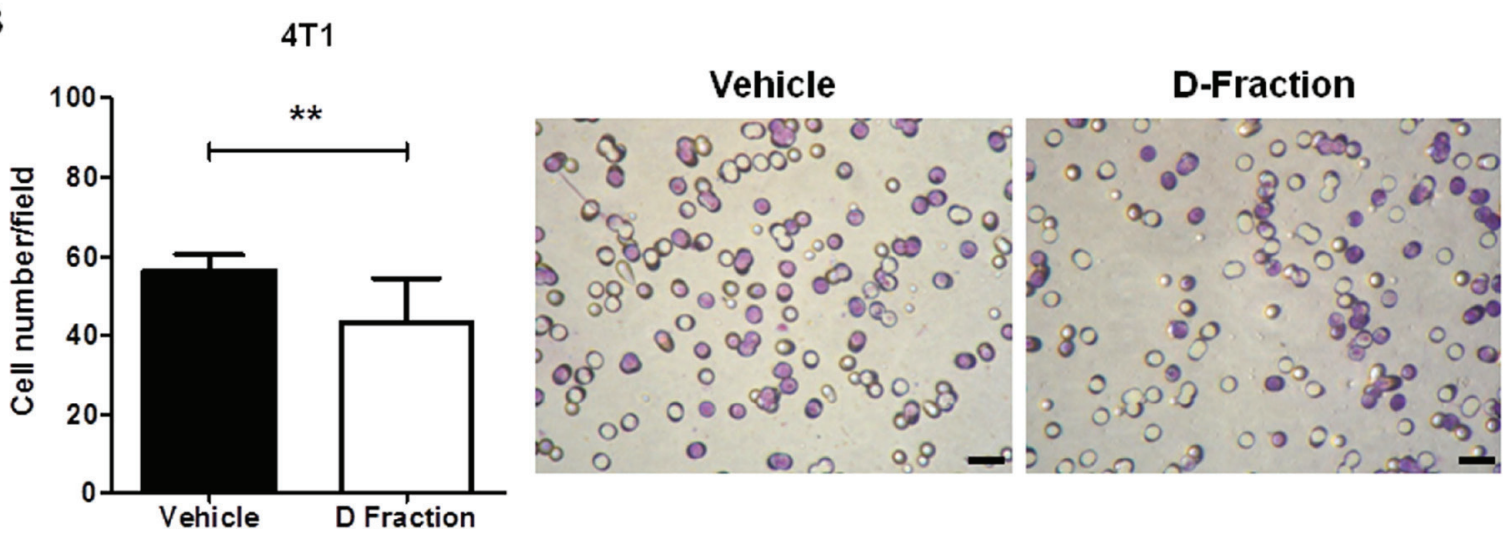

Figure 5: Maitake D-Fraction decreases invasion of TNBC MDA-MB-231 and 4T1 cells. The graph represents the mean $\left( \pm\right.$ SEM) number of (A) MDA-MB-231 and (B) 4T1 invasive cells after treatment with D-Fraction $\left(\mathrm{IC}_{50}, 12 \mathrm{~h}\right)$ or vehicle. The assays were performed in triplicate. Student's $t$ test was applied; ${ }^{* *} p<0.01,{ }^{* * *} p<0.001$. Representative pictures of cell invasion assays for each TNBC cell line. Magnification: 400×. 
In general, mushroom metabolites with antitumor activity exert their effect exclusively by activation of the immune response of the host organism or acting directly on the tumor cell, interfering with particular cellular signal transduction pathways linked to cancer development and progression [53-55]. Unlike these, Maitake D-Fraction, attacks tumor cells both by their immunostimulatory capacity [14-21] and independently of the immune system [22-29]. Particularly with respect to the immunoindependent antitumor effect of D-Fraction, it has been observed to be tumor-type specific.

In this study, we demonstrated for the first time that Maitake D-Fraction is able to act directly on TNBC MDAMB-231 and 4T1 cells, by modulating different cellular

A
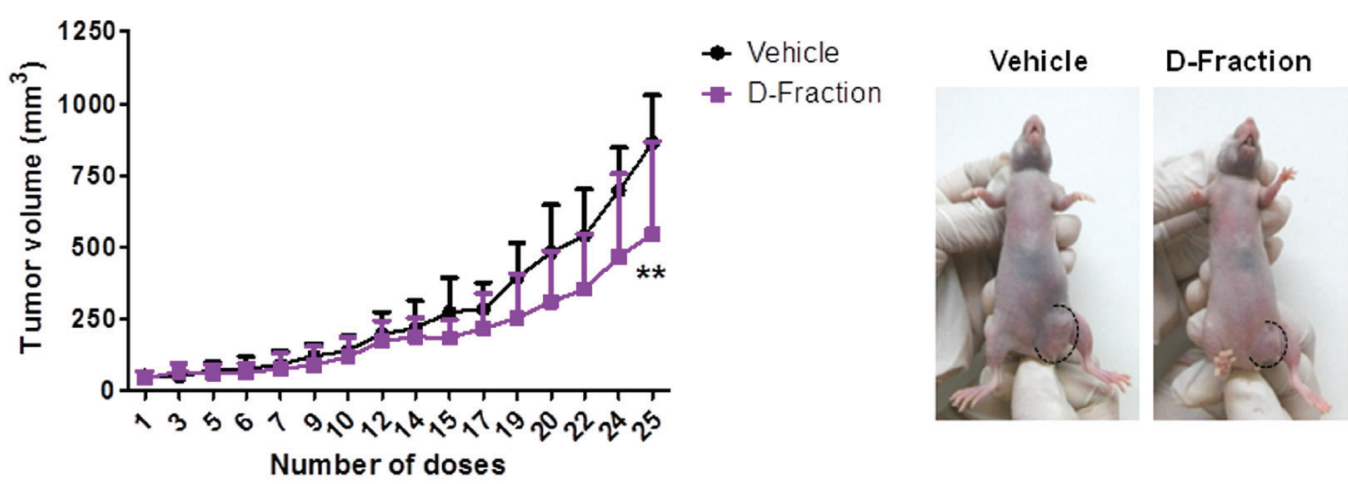

B
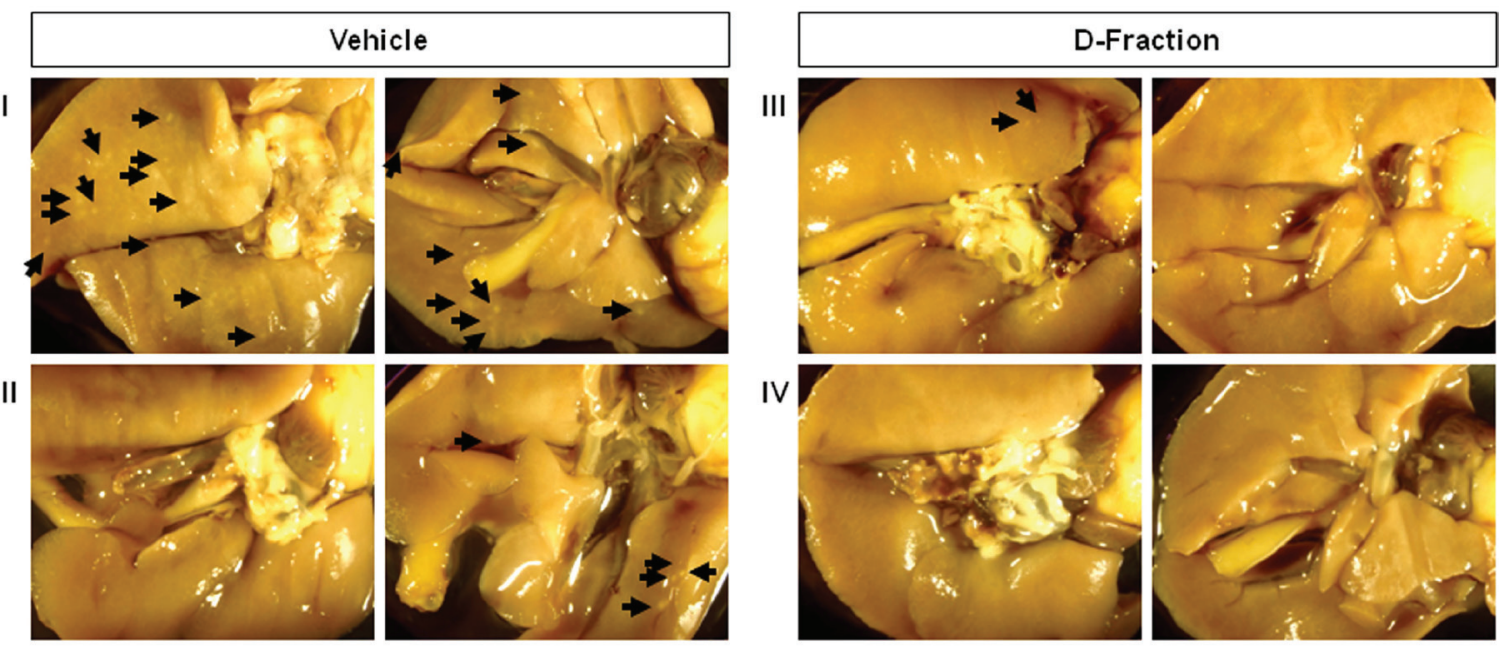

C
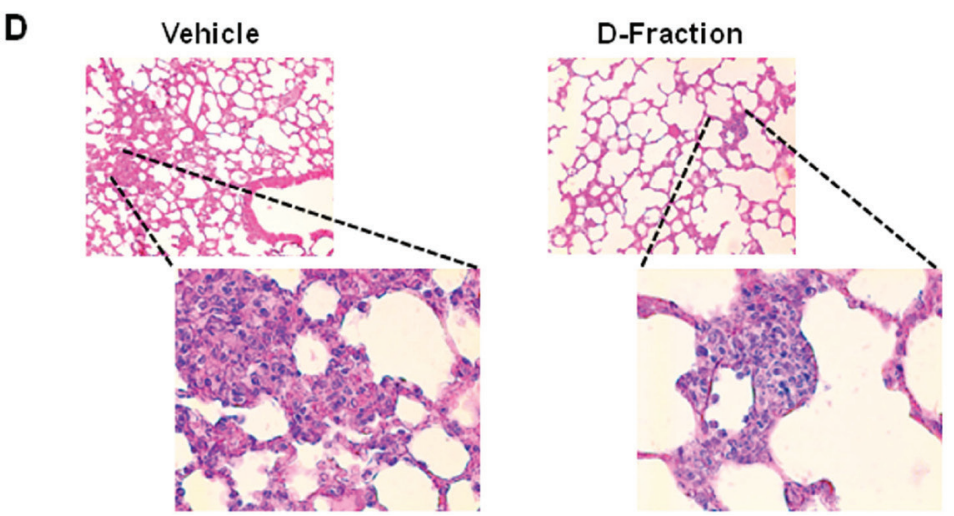

Figure 6: Maitake D-Fraction retards tumor growth and reduces the number of lung metastases in a xenograft model of TNBC human cells. Tumor-bearing nude mice were treated with D-Fraction $\left(21.87 \mathrm{mg} \times \mathrm{Kg}^{-1} \times\right.$ day $\left.^{-1} ; n=5\right)$ or vehicle $(n=5)$. (A) Graph showing the kinetic of tumor growth and representative images of tumor-bearing mice treated with D-Fraction or vehicle at the end of the treatment (on the right). Values are the mean \pm SD. Two-way ANOVA and Bonferroni post test were used. (B) Representative pictures of the lung metastases from mice treated with vehicle (I and II) and D-Fraction (III and IV). Shown are the two sides of lungs. (C) Graph showing the quantification of the number of lung metastases per mouse. The red lines represent the median value. MannWhitney $U$ test was performed. (D) Representative pictures of the metastases observed in H\&E-stained lung slides from mice treated with vehicle and D-Fraction. Magnification: $100 \times$ and $400 \times$, for the amplifications. ${ }^{*} p<0.05,{ }^{* *} p<0.01$. 
capabilities whose deregulation lead to the development and progression of cancer and thus decreasing the highly aggressive phenotype of these tumor cells.

The present data show that Maitake D-Fraction decreases the viability of TNBC MDA-MB-231 cells through apoptosis induction. In our previous works we have demonstrated that D-Fraction also decreases the viability of hormone-dependent MCF7 [24] and hormoneindependent LM3 breast cancer cells [25]. These results indicate that Maitake D-Fraction affects breast cancer cell viability regardless of hormone receptors and HER2 status of tumor cells. This capability exerted by D-Fraction is not a common feature of medicinal mushrooms extracts. Of 38 extracts evaluated on MCF7 (hormone-dependent), BT-20 and MDA-MB-231 (TNBC) cells, only three of them were able to affect the cell viability of both tumor subtypes [52]. In general, mushrooms extracts only decrease the viability of ER positive breast cancer cells by inhibiting aromatase activity $[53,54,56,57]$. In this way, Maitake D-Fraction is a potential agent with broad-spectrum antitumor activity against the different breast tumor subtypes: hormonedependent, hormone-independent and triple-negative.

One of the main limitations in cancer treatment is the lack of therapies that can efficiently prevent the development of metastasis. Metastatic breast cancer is essentially incurable and is responsible for most of breast cancer deaths. It is known that TNBC patients have a higher risk of metastatic disease, compared to patients with other breast cancer subtypes [6]. Moreover, patients with metastatic TNBC have a shorter survival time [58]. Despite the importance of the metastatic process, therapeutic approaches of mushrooms extracts against the "metastatic phenotype" are far behind in terms of development when compared to the mushroom extract effects against other "hallmarks of cancer" such as sustained proliferation and evasion of apoptosis. Therefore, in the present work, in addition to demonstrating that proteoglucan decreases the viability of TNBC MDA-MB-231 cells, we also evaluated its effect on the metastatic potential of these tumor cells. We found that D-Fraction affects different abilities employed by tumor cells in the different stages of the metastatic process.

On the one hand, Maitake D-Fraction significantly increased E-cadherin expression in TNBC MDA-MB-231. E-cadherin is one of the main cell adhesion molecules between epithelial cells [38, 39] and its loss of expression is considered a hallmark in the EMT [37]. It is well known that EMT is a key process in the progression of epithelial cancer by which tumor cell loses cell-cell adhesion, detaches itself from the primary tumor and assumes a mesenchymal-like phenotype to migrate and invade the surrounding tissue $[30,37]$. Furthermore, it is well known that the cytoplasmic domains of E-cadherin interact with $\beta$-catenin, and this reciprocal action is crucial for the adhesive function of E-cadherin [40]. Under pathologic conditions such as cancer, the E-cadherin/ $\beta$-catenin complex is generally destroyed, leading to impairment of cell-cell adhesion [40]. Upon loss of its membrane location, free $\beta$-catenin accumulates in the cytoplasm and/or translocates to the nucleus. In patients with breast cancer, the cytoplasmic and/or nuclear localization of $\beta$-catenin has been correlated with poor prognosis [40-45]. In this work, Maitake D-Fraction decreased the presence of $\beta$-catenin in the cytoplasm/nucleus of MDA-MB-231 cells and promoted its membrane localization suggesting its interaction with E-cadherin. Altogether, our result suggests that D-Fraction decreases the invasive potential of TNBC MDA-MB-231 cells by favoring intercellular adhesion and promoting its epithelial phenotype.

The present data also show that Maitake D-Fraction decreases the migratory capability of TNBC MDA-MB-231 cells. On the one hand, we demonstrated that proteoglucan affects the actin cytoskeleton re-organization, which is an essential mechanism of cellular motility for most types of cell migration [59]. Filopodia, lamellipodia and stress fibers are different kinds of actin structures, which generate the intracellular forces necessary to cell translocation [30, 31]. Particularly, D-Fraction decreases the motility of the MDA-MB-231 cells by reducing the presence of stress fibers in them. In concordance with this, MDA-MB-231 cells have been classified as mesenchymal-like cell line [60] and a characteristic of mesenchymal-migrating cells is the presence of actin stress fibers $[30,37]$. On the other hand, we demonstrated that Maitake D-Fraction is able to specifically affect the mesenchymal migration mode, which is adopted by tumor cells after the acquisition of mesenchymal phenotype through EMT [61]. This type of motility is dependent on the use of proteases to degrade the surrounding ECM and generate a path through which cells can invade $[62,63]$. There is a strong correlation between the expression, secretion and/or activation of different proteases with the tumor ability to metastasize [33]. In this work, Maitake D-Fraction was shown to decrease the activity of MMP-2 and MMP-9 secreted by TNBC MDAMB-231 cells, two MMPs clearly linked to breast cancer metastatic potential $[64,65]$. In this context, D-Fraction could be employed as an inhibitor of MMPs activity to reduce the invasive potential of TNBC.

Unfortunately, cancer cells may maintain migratory capacity after the abolition of their ability to degrade ECM $[63,66]$. It has been shown that in the presence of proteolytic inhibitors, MDA-MB-231 cells spontaneously switch from proteolytic mesenchymal-like migration to protease independent amoeboid-like migration, in order to continue migrating [67]. This cellular plasticity makes it difficult to repress cancer cell invasion by using only protease inhibitors. However, another fundamental requirement for switching to an amoeboid migration is the loss of cell-substrate adhesion [59]. In this work, we demonstrated that Maitake D-Fraction increases the adhesion of MDA-MB-231 cells to substrate, thereby decreasing their metastatic ability. Therefore, this result 
suggests that the proteoglucan could limit the ability of TNBC cells to adopt protease-independent amoeboid-like migration. In concordance with our result, [68] and [69] have reported that decreases in cell-substrate adhesion in LMM3 (murine breast cancer line) and MDA-MB-231 respectively, is associated with an increase in their migratory and metastatic potential.

In concordance with all the effects of Maitake D-Fraction tending to decrease invasive ability of MDA-MB-231 cells, the invasion assay with Matrigel demonstrated that proteoglucan effectively decreases invasive capacity of these highly aggressive TNBC cells.

Finally, in a xenograft model of TNBC human cells we demonstrated that Maitake D-Fraction treatment retards tumor growth and reduces the number of spontaneous lung metastases. These in vivo effects corroborate the in culture effects of D-Fraction that we demonstrated in MDAMB-231 cells.

In conclusion, we demonstrate that Maitake D-Fraction decreases the viability of TNBC MDAMB-231 cells through apoptosis induction and affects diverse abilities employed by tumor cells in the different stages of the metastatic process, thus decreasing the highly aggressive phenotype of these tumor cells. D-Fraction increases the adhesion of MDA-MB-231 cells between them, by increasing the expression of E-cadherin and promoting the membrane localization of $\beta$-catenin, and increasing the adhesion of MDA-MB-231 to the substrate. Also, the proteoglucan decreases the motility of MDA-MB-231 cells by affecting the actin cytoskeleton rearrangements. Furthermore, D-Fraction decreases the proteolytic activity of MMP-2 and MMP9 secreted by MDA-MB-231 cells. The coupling of all these effects led to a decrease in the invasive capacity of MDA-MB-231 cells after D-Fraction treatment. In concordance with these results, we also demonstrate that Maitake D-Fraction treatment retards tumor growth and reduces the number of lung metastases in a xenograft model of TNBC human cells. Therefore, these results widen the antitumoral spectrum of D-Fraction within the heterogeneity of breast cancer and allow us to infer that Maitake D-Fraction may serve as a novel natural drug against TNBC.

\section{MATERIALS AND METHODS}

\section{Bioactive maitake D-Fraction}

D-Fraction is a proteoglucan extracted from the medicinal mushroom Grifola frondosa (Maitake). In this work we use Maitake D-Fraction ${ }^{\circledR}$ Pro 4X Liquid, which is made from D-Fraction extract, vegetable glycerin and water by Mushroom Wisdom, Inc. (formerly Maitake Products, Inc.) New Jersey, USA. Maitake D-Fraction ${ }^{\circledR}$ Pro 4X Liquid was prepared by a standardized procedure developed by Mushroom Wisdom, Inc. and does not contain alcohol, sugar, yeast, mold, corn, salt, wheat, artificial color, preservatives or synthetic pesticides or fertilizers.

\section{Cell culture}

MDA-MB-231 human and 4T1 murine TNBC cell lines were employed and were a generous gift from Instituto de Oncología Ángel Roffo and UBA-IFIBYNECONICET, respectively. The cells were cultured in RPMI (Sigma) supplemented with $10 \%(\mathrm{v} / \mathrm{v})$ fetal bovine serum (FBS, Gibco), L-glutamine (5 mM, Gibco), penicillin (100 U/mL, Gibco) and streptomycin $(100 \mu \mathrm{g} / \mathrm{mL}$, Gibco) at $37^{\circ} \mathrm{C}$ in a humidified $5 \% \mathrm{CO}_{2}$ air atmosphere.

\section{Cell viability assays}

The MDA-MB-231 and 4T1 cells were plated at a density of 3500-3000 cells/well respectively into 96 multi-well dishes in complete medium. They were treated with $30,300,750,1500$ and $2250 \mu \mathrm{g} / \mathrm{mL}$ of D-Fraction or vehicle for 24,48 and $72 \mathrm{~h}$. Then, they were counted manually using a hemocytometer, as previously described [70]. The experiment was repeated at least twice and performed in quadruplicate. Half maximal inhibitory concentrations $\left(\mathrm{IC}_{50}\right)$ of D-Fraction were calculated using the sigmoidal dose-response equation employing GraphPad Prism 5.00 program. Additionally, cell viability was assessed by 4-[3-(4-Iodophenyl)-2-(4-nitrophenyl)2H-5-tetrazolio]-1,3 benzene disulfonate (WST-1) colorimetric assay (Roche) as previously described [25]. Vehicle treatment did not exert effects over cellular viability when compared to non-treated cells.

\section{Cell cycle analysis}

Cell cycle analysis was performed as previously described [71]. In brief, MDA-MB-231 cells were treated with D-Fraction $\left(\mathrm{IC}_{50}, 24 \mathrm{~h}\right)$ or vehicle. After that, they were stained with PI (Roche), and analyzed for DNA content by FACScan Calibur Becton Dickinson. Data were analyzed by CellQuest software (Becton Dickinson). At least 100,000 cells were analyzed for each sample.

\section{Apoptosis analysis}

Apoptosis was analyzed by flow cytometry using Annexin V-FITC (AV)/PI double staining as previously described [70]. In brief, MDA-MB-231 cells were treated with D-Fraction $\left(\mathrm{IC}_{50}, 24 \mathrm{~h}\right.$ ) or vehicle. The cells were counted using FACScan Calibur Becton Dickinson and data were analyzed by CellQuest software (Becton Dickinson). We determined the total apoptotic population including both early apoptotic cells (AV+/IP-) and late apoptotic cells $(\mathrm{AV}+/ \mathrm{IP}+)$. At least 100,000 cells were analyzed for each sample. 


\section{Cell migration assay}

Cell migration was studied by employing the wound healing assay. Briefly, the cells were seeded in $35-\mathrm{mm}$ Petri dishes and cultured until confluence. MDA-MB-231 and $4 \mathrm{~T} 1$ cells were treated with D-Fraction $\left(\mathrm{IC}_{50}\right)$ or vehicle. The cells were scraped with a $200 \mu \mathrm{L}$ micropipette tip, denuding a strip of the monolayer. Then, they were observed and photographed every $4 \mathrm{~h}$ and for a shorter time than the doubling time $\left(\mathrm{T}_{2}\right)$ of the cell line (MDA-MB-231 $\mathrm{T}_{2}=29 \mathrm{~h} ; 4 \mathrm{~T} 1 \mathrm{~T}_{2}=15.5 \mathrm{~h}$ ). Images were captured with an inverted microscope (Nikon Eclipse TE2000-S) equipped with a digital camera (Nikon Coolpix S4). The uncovered wound area was measured and quantified at different intervals with Fiji (Fiji Is Just ImageJ).

\section{Analysis of actin cytoskeleton}

The actin cytoskeleton was visualized by staining with rhodamine-phalloidin as previously described [25]. Briefly, MDA-MB-231 cells were seeded on glass coverslips in 35-mm Petri dishes and cultured until 50\% confluence. They were treated with D-Fraction $\left(\mathrm{IC}_{50}\right.$, $12 \mathrm{~h}$ ) or vehicle. After treatment, they were incubated with rhodamine-conjugated phalloidin (1:100) for $30 \mathrm{~min}$ and with TOPRO (1:1000) for $5 \mathrm{~min}$. Fluorescence images were acquired with a confocal microscope (Leica TCS SP2). For each replicate, at least 400 cells in 400x random fields were evaluated and the proportion of stress fiber-containing cells was determined.

\section{Immunofluorescence (IF)}

IF was performed as previously described [70]. Briefly, MDA-MB-231 cells were seeded on glass coverslips in 35-mm Petri dishes and cultured until 50\% confluence. They were treated with D-Fraction $\left(\mathrm{IC}_{50}, 12\right.$ h) or vehicle. After that, the cells were incubated with the primary antibody rabbit polyclonal anti- $\beta$-catenin (H102) (Santa Cruz Biotechnology, sc-7199) for $1 \mathrm{~h}$ and then incubated with Alexa Fluor ${ }^{\circledR} 568$ goat anti-rabbit IgG (Molecular Probes, Invitrogen) for $1 \mathrm{~h}$ in the dark. Finally they were stained with 4',6-diamidino-2-phenylindole (DAPI; 1:10000). Fluorescence images were acquired with a Nikon Eclipse E-600 microscope (Nikon, Melville, NY, USA), equipped with a SBIG model ST-7 camera (Santa Barbara Instrument Group). For each replicate, at least 400 cells in $400 \times$ random fields were evaluated and the proportion of cells expressing $\beta$-catenin in membrane or cytoplasm/nucleus was determined.

\section{Preparation of conditioned media (CM)}

Secreted MMP activity was evaluated in CM. Briefly, semi-confluent cell monolayers growing in $100-\mathrm{mm}$ Petri dishes were treated with D-Fraction $\left(\mathrm{IC}_{50}\right)$ or vehicle for 6 and $12 \mathrm{~h}$. Then, the cells were incubated overnight with $4 \mathrm{~mL}$ of serum-free RPMI in presence of D-Fraction $\left(\mathrm{IC}_{50}\right)$ or vehicle. $\mathrm{CM}$ were individually collected, centrifuged (1200 rpm for $3 \mathrm{~min}$, in cold), aliquoted and stored at $-20^{\circ} \mathrm{C}$. The remaining monolayers were lysed using lysis buffer with protease inhibitors (Calbiochem) and cell protein content was determined (Bradford Reagent, Bio-Rad).

\section{Zymography for MMP-2 and MMP-9}

MMP-2 and -9 activities in CM from MDA-MB-231 cells were studied by measuring collagenolytic activity in substrate-impregnated gels, as previously described [25]. Activity bands were visualized by negative staining. Gelatinolytic bands were visualized using a transilluminator and measured with Fiji (Fiji Is Just ImageJ). Data were normalized to total protein concentration.

\section{Cell adhesion assay}

Cell adhesion was evaluated as previously described [72], with some modifications. Briefly, MDA-MB-231 cells were treated with D-Fraction $\left(\mathrm{IC}_{50}, 12 \mathrm{~h}\right)$ or vehicle. Then, cells were seeded into 96-well culture plates (10000 cells/well; 3 wells/condition) and were allowed to adhere. The viability of the seeded cells was verified using Trypan Blue (Sigma) exclusion assay. After $30 \mathrm{~min}, 1 \mathrm{~h}, 2 \mathrm{~h}, 5 \mathrm{~h}$, $8 \mathrm{~h}, 10 \mathrm{~h}$ and $12 \mathrm{~h}$, non-adherent cells were removed by gentle washing and attached cells were stained with $0.1 \%$ (w/v) Crystal Violet (Sigma) for 20 min. Cells attached to the culture plate were observed with an inverted microscope (Nikon Eclipse TE2000-S), equipped with a digital camera (Nikon Coolpix S4). For each replicate, ten randomly selected fields were photographed and the cells were counted with Fiji (Fiji Is Just ImageJ).

\section{Western blot}

The MDA-MB-231 cells were plated into dishes containing complete medium and treated with D-Fraction $\left(\mathrm{IC}_{50}\right)$ or vehicle for $15 \mathrm{~min}, 60 \mathrm{~min}, 12 \mathrm{~h}$ or $18 \mathrm{~h}$. The treatment time varies according to the protein under study and, particularly for evaluating the expression of phosphoAkt-S473 (pAkt-S473) and phospho-ERK1/2 (pERK1/2), cells were previously deprived of FBS for $18 \mathrm{~h}$. Then, they were lysed and the total protein concentrations were determined as previously described [25]. Lysates were prepared to examine the expression of pAkt-S473, total Akt (Akt), pERK1/2, total ERK1/2 (ERK1/2), Bax, Bcl-2, E-cadherin and $\beta$-catenin. Primary antibodies used were rabbit polyclonal anti-phospho-Akt (Ser 473) (Cell Signaling, \#9271S), rabbit polyclonal anti-pERK1/2 (Cell Signaling, \#9101), rabbit polyclonal anti-Bax (N-20) (Santa Cruz Biotechnology, sc-493), mouse monoclonal anti-Bcl-2 (C-2) (Santa Cruz Biotechnology, sc-7382), rabbit polyclonal anti-E-cadherin (H-108) (Santa Cruz Biotechnology, sc-7870) and rabbit polyclonal anti- $\beta$ - 
catenin (H-102) (Santa Cruz Biotechnology, sc-7199). Rabbit polyclonal anti-Akt (Cell Signaling, \#9272) and mouse monoclonal anti-ERK1/2 (C-9) (Santa Cruz Biotechnology, sc-514302) were used for normalization of Akt and ERK1/2 phosphorylation. Anti- $\beta$-actin (C-11, polyclonal goat, Santa Cruz Biotechnologies, sc-1615) was used as internal control for protein loading and analysis.

\section{Cell invasion assay}

The invasion of cancer cells was assessed in transwell chambers (Millipore) with Matrigel (BD Bioscieces) as previously described [70]. In brief, each transwell was coated with $100 \mu \mathrm{L}$ of a 1:3 matrigel in cold serum-free RPMI. The lower chamber was filled with $0.6 \mathrm{~mL}$ of complete RPMI medium. MDA-MB-231 or 4T1 cells (12500 cells/well) and D-Fraction $\left(\mathrm{IC}_{50}\right)$ or vehicle were suspended in complete RPMI medium $(0.4 \mathrm{~mL} /$ well $)$, placed in the upper transwell chambers in triplicates, and incubated for $12 \mathrm{~h}$ at $37^{\circ} \mathrm{C}$. After incubation, the invading cells on the lower side of the membrane were stained with $0.5 \%$ (w/v) Crystal Violet (Sigma) for $5 \mathrm{~min}$. For each replicate, 10 randomly selected fields were photographed and the cells were counted with Fiji (Fiji Is Just ImageJ).

\section{Xenograft murine model of human breast cancer}

In vivo studies were conducted in accordance with the National Institutes of Health (NIH) Guide for the Care and Use of Laboratory Animals. Six-week-old virgin female N:NIH(S)-Fox $1^{\text {nu }}$ mice, weighing around $24 \mathrm{~g}$, were purchased from Facultad de Ciencias Veterinarias (La Plata, Argentina). Animals were given free access to water and food, and were housed in a climate-controlled room with a 12-h light/12-h dark cycle. Ten animals were injected with MDA-MB-231 cells as previously described [73], with some modifications. In brief, $4.8 \times 10^{6} \mathrm{MDA}-$ MB-231 cells suspended in $75 \mu \mathrm{L}$ of serum-antibioticfree RPMI and $75 \mu \mathrm{L}$ of Matrigel (BD Bioscieces) were implanted subcutaneously in the mammary fat pad of the nude mice. The cells were implanted using cold 1-mL syringes with needles $(\mathrm{BD}) 0.80 \times 25 \mathrm{~mm}(21 \mathrm{Gx} 1)$. When tumors reached a width $>30 \mathrm{~mm}$, MDA-MB-231 tumorbearing mice were randomly divided into two groups and were injected as indicated previously [25]:1) 5 mice with D-Fraction $(21.87 \mathrm{mg} / \mathrm{Kg}$ in $50 \mu \mathrm{L}$ of saline) and 2) 5 mice with vehicle of D-Fraction (glycerin-water in $50 \mu \mathrm{L}$ of saline). Mice were injected subcutaneously in the tumor periphery five times a week for five weeks (total doses $=25$ ). Tumor growth was measured each other day with digital calipers and tumor volume was calculated as $\pi / 6 \times a \times b^{2}$, where $a$ is the length and $b$ is the width in millimeters. At the end-point animals were sacrificed by cervical dislocation. Lungs were removed and fixed in Bouin's solution. The superficial lung metastases per mouse were counted by two investigators with the aid of a Stereo Microscope (Nikon SM Z1500) coupled with High-Intensity Illuminator (Nikon NI-150) and a digital camera (Nikon DXM 1200F). After that, the lungs were processed into paraffin by standard procedures, fivemicrometer sections were obtained and stained with H\&E for histological confirmation of the metastasis.

\section{Statistical analysis}

The GraphPad Prism software package, version 5.00 was used for collection, processing and statistical analysis of all data. Cell viability, MMP-s activity, adhesion, migration, cell cycle assays, relative Akt and ERK1/2 phosphorylation and in vivo comparison of the tumor volume were analyzed with two-way Analysis Of Variance (ANOVA) and Bonferroni post tests. Apoptosis assay, IF, WB of Bax, Bcl-2, E-cadherin and $\beta$-catenin, cell invasion assay and effects on actin cytoskeleton were analyzed with Student's $t$ test. Comparison of the number of lung metastases among different groups was analyzed by the non-parametrical Mann-Whitney $U$ test. Statistical significance was determined at $p<0.05$ level.

\section{Abbreviations}

ANOVA: analysis of variance; AV: Annexin V-FITC; CM: conditioned media; ECM: extracellular matrix; EMT: epithelial-mesenchymal transition; ER: estrogen receptor; FBS: fetal bovine serum; HER2: human epidermal growth factor receptor 2; H\&E: Hematoxylin and Eosin; $\mathrm{IC}_{50}$ : half maximal inhibitory concentrations; IF: immunofluorescence; MMP: matrix metalloproteinase; PI: propidium iodide; $\mathrm{PR}$ : progesterone receptor; $\mathrm{T}_{2}$ : doubling time; TNBC: triple-negative breast cancer; WB: western blot; WST-1: 4-[3-(4-Iodophenyl)-2-(4nitrophenyl)-2H-5-tetrazolio]-1,3 benzene disulfonate.

\section{Author contributions}

AEN conceived and performed the study and wrote the paper. FMJ collaborated with the zymography assays, WB and murine model. FME collaborated with the apoptosis assays. GNA collaborated with the IF assays and H\&E staining. LRA provided the technical support related to flow cytometry and its analysis. GJA collaborated with the cell viability assays, murine model and paper revision. FMM and CAC supervised and coordinated the study, revised the paper and collaborated with the funding acquisition. All authors approved the final version of the manuscript.

\section{ACKNOWLEDGMENTS}

We would like to thank Dra. Gabriela A. Balogh (Laboratorio de Biología Celular y Molecular, BIOMED 
UCA-CONICET, Buenos Aires, Argentina) for the provision of Maitake D-Fraction ${ }^{\circledR}$ Pro 4X Liquid which was produced by Mushroom Wisdom, Inc. (formerly Maitake Products, Inc.) New Jersey, USA. We are grateful to Dra. Elisa Bal de Kier Joffe (Instituto de Oncología Ángel Roffo, Buenos Aires, Argentina) and Dra. Edith Kordon (Instituto de Fisiología, Biología Molecular y Neurociencias UBA-IFIBYNE-CONICET, Buenos Aires, Argentina) for providing the MDA-MB-231 and 4T1 cells, respectively.

\section{CONFLICTS OF INTEREST}

All authors declare that there are no conflicts of interest.

\section{FUNDING}

This work was supported by the Agencia Nacional de Promoción Científica y Tecnológica (ANPCyT, PICTs 2012-1595 and 2012-0966) and by Universidad Nacional del Sur, Bahía Blanca, Buenos Aires, Argentina (PGI 24/ B172).

\section{REFERENCES}

1. Stewart BW, Wild CP, eds. World Cancer Report 2014. Lyon, France: International Agency for Research on Cancer, World Health Organization. 2014. ISBN-13: 978-92-832-0443-5.

2. GLOBOCAN. International Agency for Research on Cancer (IARC). GLOBOCAN 2012: estimates of the incidence of, mortality and prevalence worldwide in 2012. http:// globocan.iarc.fr/. Accessed 29 March 2017.

3. Jemal A, Bray F, Center MM, Ferlay J, Ward E, Forman D. Global cancer statistics. CA Cancer J Clin. 2011; 61:69-90. https://doi.org/10.3322/caac.20107.

4. Foulkes WD, Smith IE, Reis-Filho JS. Triple-negative breast cancer. N Engl J Med. 2010; 363:1938-1948. https:// doi.org/10.1056/NEJMra1001389.

5. Amos KD, Adamo B, Anders CK. Triple-negative breast cancer: an update on neoadjuvant clinical trials. Int J Breast Cancer. 2012; 2012: 385978. https://doi. org/10.1155/2012/385978.

6. Yadav BS, Chanana P, Jhamb S. Biomarkers in triple negative breast cancer: A review. World J Clin Oncol. 2015; 6:252-263. https://doi.org/10.5306/wjco.v6.i6.252.

7. Jamdade VS, Sethi N, Mundhe NA, Kumar P, Lahkar M, Sinha N. Therapeutic targets of triple-negative breast cancer: a review. Br J Pharmacol. 2015; 172:4228-4237. https://doi.org/10.1111/bph.13211.

8. Nounou MI, ElAmrawy F, Ahmed N, Abdelraouf $\mathrm{K}$, Goda S, Syed-Sha-Qhattal H. Breast cancer: conventional diagnosis and treatment modalities and recent patents and technologies. Breast Cancer (Auckl). 2015; 9:17-34. https:// doi.org/10.4137/BCBCR.S29420.

9. Newman DJ, Cragg GM. Natural products as sources of new drugs over the 30 years from 1981 to 2010. J Nat Prod. 2012; 75:311-335. https://doi.org/10.1021/np200906s.

10. Patel S, Goyal A. Recent developments in mushrooms as anti-cancer therapeutics: a review. 3 Biotech. 2012; 2:1-15. https://doi.org/10.1007/s13205-011-0036-2.

11. De Silva DD, Rapior S, Fons F, Bahkali AH, Hyde KD. Medicinal mushrooms in supportive cancer therapies: an approach to anti-cancer effects and putative mechanisms of action. Fungal Divers. 2012; 55:1-35. https://doi. org/10.1007/s13225-012-0151-3.

12. Glauco S, Jano F, Paolo G, Konno S. Safety of Maitake D-Fraction in healthy patients. Assessment of common hematologic parameters. Altern Comp Ther. 2004; 10:228230. https://doi.org/10.1089/1076280041580341.

13. Mayell M. Maitake extracts and their therapeutic potential. Altern Med Rev. 2001; 6:48-60.

14. Kodama N, Komuta K, Sakai N, Nanba H. Effects of D-Fraction, a polysaccharide from Grifola frondosa on tumor growth involve activation of NK cells. Biol Pharm Bull. 2002; 25:1647-1650. https://doi.org/10.1248/bpb. 25.1647

15. Hishida I, Nanba H, Kuroda H. Antitumor activity exhibited by orally administered extract from fruit body of Grifola frondosa (maitake). Chem Pharm Bull (Tokyo). 1988; 36:1819-1827.

16. Kodama N, Yamada M, Nanba H. Addition of Maitake D-fraction reduces the effective dosage of vancomycin for the treatment of Listeria-infected mice. Jpn J Pharmacol. 2001; 87:327-332. https://doi.org/10.1254/jjp.87.327.

17. Sanzen I, Imanishi N, Takamatsu N, Konosu S, Mantani N, Terasawa K, Tazawa K, Odaira Y, Watanabe M, Takeyama M, Ochiai H. Nitric oxide-mediated antitumor activity induced by the extract from Grifola frondosa (Maitake mushroom) in a macrophage cell line, RAW264.7. J Exp Clin Cancer Res. 2001; 20:591-597.

18. Inoue A, Kodama N, Nanba H. Effect of maitake (Grifola frondosa) D-Fraction on the control of the $\mathrm{T}$ lymph node Th-1/Th-2 proportion. Biol Pharm Bull. 2002; 25:536-540. https://doi.org/10.1248/bpb.25.536.

19. Harada N, Kodama N, Nanba H. Relationship between dendritic cells and the D-fraction-induced Th-1 dominant response in $\mathrm{BALB} / \mathrm{c}$ tumor-bearing mice. Cancer Lett. 2003; 192:181-187. https://doi.org/10.1016/ S0304-3835(02)00716-4.

20. Kodama N, Asakawa A, Inui A, Masuda Y, Nanba H. Enhancement of cytotoxicity of NK cells by D-Fraction, a polysaccharide from Grifola frondosa. Oncol Rep. 2005; 13:497-502. https://doi.org/10.3892/or.13.3.497.

21. Kodama N, Harada N, Nanba H. A polysaccharide, extract from Grifola frondosa, induces Th-1 dominant responses in carcinoma-bearing BALB/c mice. Jpn J Pharmacol. 2002; 90:357-60. https://doi.org/10.1254/jjp.90.357. 
22. Fullerton SA, Samadi AA, Tortorelis DG, Choudhury MS, Mallouh C, Tazaki H, Konno S. Induction of apoptosis in human prostatic cancer cells with beta-glucan (Maitake mushroom polysaccharide). Mol Urol. 2000; 4:7-13.

23. Konno S. Synergistic potentiation of D-fraction with vitamin $\mathrm{C}$ as possible alternative approach for cancer therapy. Int J Gen Med. 2009; 2:91-108. https://doi.org/10.2147/IJGM.S5498.

24. Soares R, Meireles M, Rocha A, Pirraco A, Obiol D, Alonso E, Joos G, Balogh G. Maitake (D Fraction) mushroom extract induces apoptosis in breast cancer cells by BAK-1 gene activation. J Med Food. 2011; 14:563-572. https://doi.org/10.1089/jmf.2010.0095.

25. Alonso EN, Ferronato MJ, Gandini NA, Fermento ME, Obiol DJ, López Romero A, Arévalo J, Villegas ME, Facchinetti MM, Curino AC. Antitumoral effects of D-Fraction from Grifola Frondosa (Maitake) mushroom in breast cancer. Nutr Cancer. 2017; 69:29-43. https://doi.org /10.1080/01635581.2017.1247891

26. Alexander B, Fishman AI, Eshghi M, Choudhury M, Konno S. Induction of cell death in renal cell carcinoma with combination of D-fraction and vitamin C. Integr Cancer Ther. 2013; 12:442-448. https://doi.org/10.1177/1534735412473643.

27. Degen M, Alexander B, Choudhury M, Eshghi M, Konno S. Alternative therapeutic approach to renal-cell carcinoma: induction of apoptosis with combination of vitamin $\mathrm{K} 3$ and D-fraction. J Endourol. 2013; 27:1499-1503. https://doi. org/10.1089/end.2013.0207.

28. Konno S. Potential growth inhibitory effect of maitake D-fraction on canine cancer cells. Vet Ther. 2004; 5:263-271.

29. Alonso EN, Orozco M, Eloy Nieto A, Balogh GA. Genes related to suppression of malignant phenotype induced by Maitake D-Fraction in breast cancer cells. J Med Food. 2013; 16:602-617. https://doi.org/10.1089/jmf.2012.0222.

30. Chan E, Saito A, Honda T, Di Guglielmo GM. The acetylenic tricyclic bis(cyano enone), TBE-31 inhibits nonsmall cell lung cancer cell migration through direct binding with actin. Cancer Prev Res (Phila). 2014; 7:727-737. https://doi.org/10.1158/1940-6207.CAPR-13-0403.

31. Ebeling S, Naumann K, Pollok S, Wardecki T, VidalY-Sy S, Nascimento JM, Boerries M, Schmidt G, Brandner JM, Merfort I. From a traditional medicinal plant to a rational drug: understanding the clinically proven wound healing efficacy of birch bark extract. PLoS One. 2014; 9: e86147. https://doi.org/10.1371/journal. pone. 0086147.

32. Vartak DG, Gemeinhart RA. Matrix metalloproteases: underutilized targets for drug delivery. J Drug Target. 2007; 15:1-20. https://doi.org/10.1080/10611860600968967.

33. Roy DM, Walsh LA. Candidate prognostic markers in breast cancer: focus on extracellular proteases and their inhibitors. Breast Cancer (Dove Med Press). 2014; 6:81-91. https:// doi.org/10.2147/BCTT.S46020.

34. Chandolia B, Basu SK, Kumar M. Can MMP-9 be a prognosticator marker for oral squamous cell carcinoma? J
Clin Diagn Res. 2016; 10:ZC09-13. https://doi.org/10.7860/ JCDR/2016/14128.7034.

35. Okegawa T, Pong RC, Li Y, Hsieh JT. The role of cell adhesion molecule in cancer progression and its application in cancer therapy. Acta Biochim Pol. 2004; 51:445-457.

36. Ramirez NE, Zhang Z, Madamanchi A, Boyd KL, O'Rear LD, Nashabi A, Li Z, Dupont WD, Zijlstra A, Zutter MM. The $\alpha_{2} \beta_{1}$ integrin is a metastasis suppressor in mouse models and human cancer. J Clin Invest. 2011; 121:226237. https://doi.org/10.1172/JCI42328.

37. Thiery JP, Acloque H, Huang RY, Nieto MA. Epithelialmesenchymal transitions in development and disease. Cell. 2009; 139:871-890. https://doi.org/10.1016/j. cell.2009.11.007.

38. Christofori G. New signals from the invasive front. Nature. 2006; 441:444-450. https://doi.org/10.1038/nature04872.

39. Baum B, Georgiou M. Dynamics of adherens junctions in epithelial establishment, maintenance, and remodeling. J Cell Biol. 2011; 192:907-917. https://doi.org/10.1083/ jcb.201009141.

40. Shen T, Zhang K, Siegal GP, Wei S. Prognostic value of E-cadherin and $\beta$-catenin in triple-negative breast cancer. Am J Clin Pathol. 2016; 146:603-10. https://doi. org/10.1093/ajcp/aqw183.

41. Li S, Li S, Sun Y, Li L. The expression of $\beta$-catenin in different subtypes of breast cancer and its clinical significance. Tumour Biol. 2014; 35:7693-7698. https:// doi.org/10.1007/s13277-014-1975-0.

42. Geyer FC, Lacroix-Triki M, Savage K, Arnedos M, Lambros MB, MacKay A, Natrajan R, Reis-Filho JS. $\beta$-Catenin pathway activation in breast cancer is associated with triple-negative phenotype but not with CTNNB1 mutation. Mod Pathol. 2011; 24:209-231. https://doi. org/10.1038/modpathol.2010.205.

43. Khramtsov AI, Khramtsova GF, Tretiakova M, Huo D, Olopade OI, Goss KH. Wnt/beta-catenin pathway activation is enriched in basal-like breast cancers and predicts poor outcome. Am J Pathol. 2010; 176:2911-2920. https://doi. org/10.2353/ajpath.2010.091125.

44. Hayes MJ, Thomas D, Emmons A, Giordano TJ, Kleer CG. Genetic changes of Wnt pathway genes are common events in metaplastic carcinomas of the breast. Clin Cancer Res. 2008; 14:4038-4044. https://doi.org/10.1158/1078-0432. CCR-07-4379.

45. Fanelli MA, Montt-Guevara M, Diblasi AM, Gago FE, Tello O, Cuello-Carrión FD, Callegari E, Bausero MA, Ciocca DR. P-cadherin and beta-catenin are useful prognostic markers in breast cancer patients; beta-catenin interacts with heat shock protein Hsp27. Cell Stress Chaperones. 2008; 13:207-220. https://doi.org/10.1007/ s12192-007-0007-z.

46. van Zijl F, Krupitza G, Mikulits W. Initial steps of metastasis: cell invasion and endothelial transmigration. Mutat Res. 2011; 728:23-34. https://doi.org/10.1016/j. mrrev.2011.05.002. 
47. Chaffer CL, Weinberg RA. A perspective on cancer cell metastasis. Science. 2011; 331:1559-1564. https://doi. org/10.1126/science. 1203543.

48. Martin TA, Ye L, Sanders AJ, Lane J, Jiang WG. Cancer invasion and metastasis: molecular and cellular perspective. Austin (TX): Landes Bioscience, 2000-2013. In: Madame Curie Bioscience database (Internet). Available from: www. ncbi.nlm.nih.gov/books/NBK164700/. Accessed 18 April 2017.

49. Zhou H, Li J, Zhang Z, Ye R, Shao N, Cheang T, Wang S. RING1 and YY1 binding protein suppresses breast cancer growth and metastasis. Int J Oncol. 2016; 49:2442-2452. https://doi.org/10.3892/ijo.2016.3718.

50. Rakha EA, Reis-Filho JS, Ellis IO. Combinatorial biomarker expression in breast cancer. Breast Cancer Res Treat. 2010; 120:293-308. https://doi.org/10.1007/s10549-010-0746-x.

51. Polyak K. Heterogeneity in breast cancer. J Clin Invest. 2011; 121:3786-3788. https://doi.org/10.1172/JCI60534.

52. Gu YH, Leonard J. In vitro effects on proliferation, apoptosis and colony inhibition in ER-dependent and ER-independent human breast cancer cells by selected mushroom species. Oncol Rep. 2006; 15:417-423. https:// doi.org/10.3892/or.15.2.417.

53. Petrova RD, Wasser SP, Mahajna JA, Denchev CM, Nevo E. Potential role of medicinal mushrooms in breast cancer treatment: current knowledge and future perspectives. Int J Med Mushrooms. 2005; 7:141-46. https://doi.org/10.1615/ IntJMedMushr.v7.i12.140.

54. Zaidman BZ, Yassin M, Mahajna J, Wasser SP. Medicinal mushroom modulators of molecular targets as cancer therapeutics. Appl Microbiol Biotechnol. 2005; 67:453468. https://doi.org/10.1007/s00253-004-1787-z.

55. Ferreira IC, Vaz JA, Vasconcelos MH, Martins A. Compounds from wild mushrooms with antitumor potential. Anticancer Agents Med Chem. 2010; 10:424-436. https:// doi.org/10.2174/1871520611009050424.

56. Grube BJ, Eng ET, Kao YC, Kwon A, Chen S. White button mushroom phytochemicals inhibit aromatase activity and breast cancer cell proliferation. J Nutr. 2001; 131:3288-3293.

57. Jafaar ZM, Litchfield LM, Ivanova MM, Radde BN, Al-Rayyan N, Klinge CM. $\beta$-D-glucan inhibits endocrineresistant breast cancer cell proliferation and alters gene expression. Int J Oncol. 2014; 44:1365-1375. https://doi. org/10.3892/ijo.2014.2294.

58. Hudis CA, Gianni L. Triple-negative breast cancer: an unmet medical need. Oncologist. 2011; 16:1-11. https:// doi.org/10.1634/theoncologist.2011-S1-01.

59. Yamazaki D, Kurisu S, Takenawa T. Regulation of cancer cell motility through actin reorganization. Cancer Sci. 2005; 96: 379-386. https://doi. org/10.1111/j.1349-7006.2005.00062.x

60. Yin KB. The Mesenchymal-Like Phenotype of the MDA-MB-231 Cell Line, Breast Cancer Mehmet Gunduz. IntechOpen. 2011; 385-402. https://doi.org/10.5772/20666.
61. Zhang Y, Zhang W, Qin L. Mesenchymal-mode migration assay and antimetastatic drug screening with highthroughput microfluidic channel networks. Angew Chem Int Ed Engl. 2014; 53:2344-2348. https://doi.org/10.1002/ anie. 201309885 .

62. Fagan-Solis KD, Schneider SS, Pentecost BT, Bentley BA, Otis CN, Gierthy JF, Arcaro KF. The RhoA pathway mediates MMP-2 and MMP-9-independent invasive behavior in a triple-negative breast cancer cell line. J Cell Biochem. 2013; 114:1385-1394. https://doi.org/10.1002/jcb.24480.

63. Hecht I, Bar-El Y, Balmer F, Natan S, Tsarfaty I, Schweitzer F, Ben-Jacob E. Tumor invasion optimization by mesenchymal-amoeboid heterogeneity. Sci Rep. 2015; 5: 12121. https://doi.org/10.1038/srep12121.

64. Duffy MJ, Maguire TM, Hill A, McDermott E, O'Higgins N. Metalloproteinases: role in breast carcinogenesis, invasion and metastasis. Breast Cancer Res. 2000; 2:252257. https://doi.org/10.1186/bcr65.

65. Jezierska A, Motyl T. Matrix metalloproteinase-2 involvement in breast cancer progression: a mini-review. Med Sci Monit. 2009; 15:RA32-40.

66. Vaškovičová $K$, Szabadosová E, Čermák V, Gandalovičová A, Kasalová L, Rösel D, Brábek J. PKCa promotes the mesenchymal to amoeboid transition and increases cancer cell invasiveness. BMC Cancer. 2015; 15:326. https://doi.org/10.1186/s12885-015-1347-1.

67. Wolf K, Mazo I, Leung H, Engelke K, von Andrian UH, Deryugina EI, Strongin AY, Bröcker EB, Friedl P. Compensation mechanism in tumor cell migration: mesenchymal-amoeboid transition after blocking of pericellular proteolysis. J Cell Biol. 2003; 160:267-277. https://doi.org/10.1083/jcb.200209006.

68. Urtreger A, Porro F, Puricelli L, Werbajh S, Baralle FE, Bal de Kier Joffé E, Kornblihtt AR, Muro AF. Expression of RGD minus fibronectin that does not form extracellular matrix fibrils is sufficient to decrease tumor metastasis. Int J Cancer. 1998; 78:233-241. https://doi. org/10.1002/(SICI)1097-0215(19981005)78:2<233::AIDIJC18>3.0.CO;2-B.

69. Zou L, Jaramillo M, Whaley D, Wells A, Panchapakesa V, Das T, Roy P. Profilin-1 is a negative regulator of mammary carcinoma aggressiveness. Br J Cancer. 2007; 97:1361-1371. https://doi.org/10.1038/sj.bjc.6604038.

70. Fermento ME, Gandini NA, Salomón DG, Ferronato MJ, Vitale CA, Arévalo J, López Romero A, Nuñez M, Jung M, Facchinetti MM, Curino AC. Inhibition of p300 suppresses growth of breast cancer. Role of p300 subcellular localization. Exp Mol Pathol. 2014; 97:411-424. https:// doi.org/10.1016/j.yexmp.2014.09.019.

71. Gandini NA, Fermento ME, Salomón DG, Obiol DJ, Andrés NC, Zenklusen JC, Arevalo J, Blasco J, López Romero A, Facchinetti MM, Curino AC. Heme oxygenase-1 expression in human gliomas and its correlation with poor prognosis in patients with astrocytoma. Tumour Biol. 2014; 35:2803-2815. https://doi.org/10.1007/s13277-013-1373-z. 
72. Gueron G, Giudice J, Valacco P, Paez A, Elguero B, Toscani M, Jaworski F, Leskow FC, Cotignola J, Marti M, Binaghi M, Navone N, Vazquez E. Heme-oxygenase-1 implications in cell morphology and the adhesive behavior of prostate cancer cells. Oncotarget. 2014; 5:4087-4102. https://doi.org/10.18632/oncotarget.1826.
73. Jiang J, Thyagarajan-Sahu A, Loganathan J, Eliaz I, Terry C, Sandusky GE, Sliva D. BreastDefend ${ }^{\mathrm{TM}}$ prevents breast-to-lung cancer metastases in an orthotopic animal model of triple-negative human breast cancer. Oncol Rep. 2012; 28:1139-1145. https://doi.org/10.3892/or.2012.1936. 